\title{
Late Eocene (Priabonian) brachiopod fauna from Dnipropetrovsk, eastern Ukraine
}

\author{
MARIA ALEKSANDRA BITNER \& ARNOLD MÜLLER
}

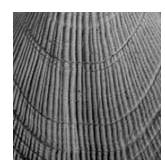

\begin{abstract}
Eleven species belonging to ten genera, i.e. Discradisca Stenzel, 1964, Novocrania Lee \& Brunton, 2001, Terebratulina d'Orbigny, 1847, Megathiris d'Orbigny, 1847, Argyrotheca Dall, 1900, Bronnothyris Popiel-Barczyk \& Smirnova, 1978, Joania Álvarez, Brunton \& Long, 2008, Megerlia King, 1850, Platidia Costa, 1852, and Lacazella Munier-Chalmas, 1880 have been identified in the Upper Eocene (Priabonian) deposits of Dnipropetrovsk, eastern Ukraine. Two species, Bronnothyris danaperensis sp. nov. and Joania ukrainica sp. nov. are described as new. The genera Discradisca, Novocrania, Megathiris, Joania, Megerlia and Platidia are reported for the first time from the Eocene of Ukraine. Additionally, the occurrence of Joania and Megerlia extends their stratigraphical range from the Oligocene to the Eocene. The fact that megathyridids and thecideides make up more than $90 \%$ of the material indicates that the fauna was living in a warm, shallow-water environment. $•$ Key words: Brachiopoda, Late Eocene, Priabonian, Ukraine, taxonomy, gastropod drilling predation.
\end{abstract}

BITNER, M.A. \& MÜLlER, A. 2017. Late Eocene (Priabonian) brachiopod fauna from Dnipropetrovsk, eastern Ukraine. Bulletin of Geosciences 92(2), 211-231 (11 figures, 1 table). Czech Geological Survey, Prague, ISSN 1214-1119. Manuscript received February 6, 2017; accepted in revised form June 7, 2017; published online June 29, 2017; issued June 30, 2017.

Maria Aleksandra Bitner, Institute of Paleobiology, Polish Academy of Sciences, ul. Twarda 51/55, 00-818 Warszawa, Poland; bitner@twarda.pan.pl•Arnold Müller, Universität Leipzig, Institut für Geophysik und Geologie, Talstraße 35, D-04103 Leipzig, Germany; gmueller@rz.uni-leipzig.de

Eocene brachiopods, although not diverse, have a widespread distribution throughout Europe and have been reported from many localities in Ukraine (Zelinskaya 1962, 1970, 1975, 1977; Makarenko 1974). Recently Systerova (2012) briefly summarized what is known of Paleogene brachiopods from this area. In earlier reports that need modern revision, Zelinskaya $(1975,1977)$ described more than 30 species and Makarenko (1974) described a new craniid species.

The aim of this paper is to describe a new brachiopod fauna from Upper Eocene deposits exposed in the Rybalsky Quarry at Dnipropetrovsk, eastern Ukraine (Fig. 1). Although rich in specimens, this fauna has never been fully described, although it was mentioned by Systerova $(2012,2014)$.

\section{Geological setting}

The Upper Eocene deposits cropping out in the Rybalsky Quarry, situated on the left bank of the Dnieper River at Dnipropetrovsk (Fig. 1), lie unconformably on Precambrian granites of the Ukrainian Shield (Müller \& Rozenberg 2003). They are represented by yellowish, light grey detrital sands up to $5 \mathrm{~m}$ thick, interpreted as shallow-water facies. The lower part $(1.5 \mathrm{~m})$ of the exposed section is composed of calcareous sands with rare macrofossils and common red-algal nodules. The upper part ( $3.5 \mathrm{~m})$ contains a rich fauna of corals, sponge spicules, molluscs, brachiopods, bryozoans and fish otoliths (Müller \& Rozenberg 2003; Amitrov \& Zhegallo 2007; Armitrov 2008; Berezovsky 2014, 2015; Sirenko \& Dell'Angelo 2015). Based on the calcareous nannoplankton those deposits were assigned to zone NP 19, corresponding to the Priabonian, Late Eocene. For detailed geological description, see Müller \& Rozenberg (2003).

\section{Material and methods}

The material described herein was collected at the Rybalsky Quarry in Dnipropetrovsk (Fig. 1). Apart from 12 specimens donated by T.A. Stefanska (Dnipropetrovsk), the specimens were picked from five large (about $100 \mathrm{~kg}$ each) bulk samples (UDR1 to UDR5 in Müller \& Rozenberg 2003), taken by the junior author in 1999 and washed on an $0.5 \mathrm{~mm}$ mesh sieve. For details of sampling see Müller \& Rozenberg (2003, pp. 362-364). Among 1356 specimens, 269 were articulated and 1087 were separate valves. The 


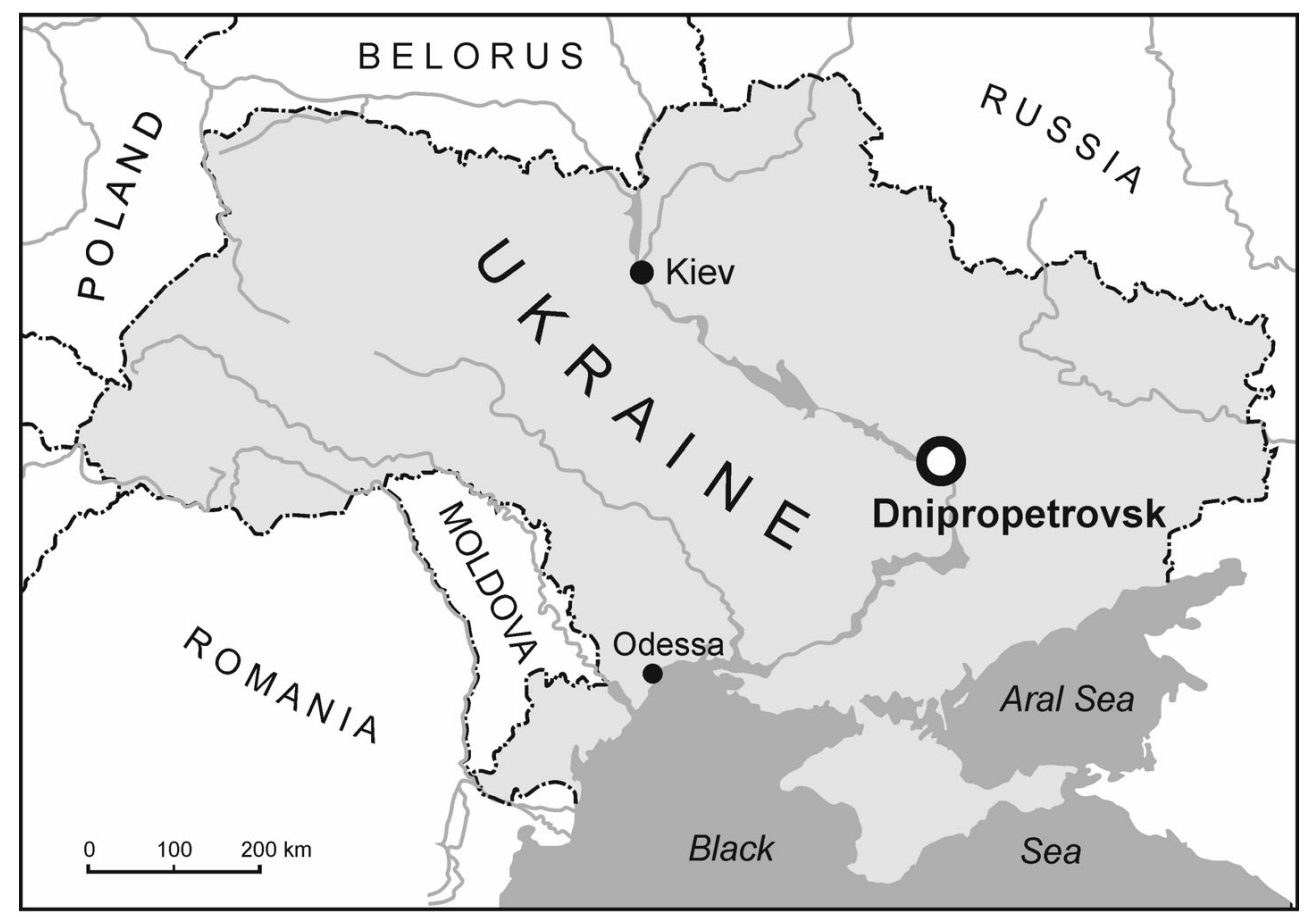

Figure 1. Sketch map showing the locality Dnipropetrovsk where brachiopods were collected.

preponderance of disarticulated valves suggests a highenergy environment and/or post-mortem transport, but if so, the good state of preservation indicates short distance transport.

Specimens selected for scanning electron microscopy were mounted on stubs, coated with platinum and examined using Philips XL-20 microscope at the Institute of Paleobiology, Warszawa. The majority of the collection is housed at the University of Leipzig, Germany under the catalogue numbers UDB 147-216. Twelve specimens donated by T. Stefanska are kept at the Institute of Paleobiology, Polish Academy of Sciences, Warszawa, under collection number ZPAL Bp.82.

\section{Systematic palaeontology}

Order Lingulida Waagen, 1885

Superfamily Discinoidea Gray, 1840

Family Discinidae Gray, 1840

\section{Genus Discradisca Stenzel, 1964}

Type species. - Orbicula antillarum d'Orbigny, 1845, by original designation of Stenzel (1964, p. 627).

\section{Discradisca sp.}

Figure 2A, B

Material. - Four poorly preserved fragments of dorsal valves.
Remarks. - This is the first record of discinid brachiopods from the Eocene of Ukraine. The ribbed neatic shell (Fig. 2B) allows attribution to the genus Discradisca (see discussion in Bitner \& Cahuzac 2013). The larval (protegulum) shell is smooth without growth lines, reaching about $0.5 \mathrm{~mm}$, while the postlarval (brephic) shell is smooth but sculptured by numerous growth lines (Fig. 2A).

Occurrence. - Late Eocene (Priabonian) of Dnipropetrovsk, Ukraine. Several species of Discradisca have been recognized in the Paleogene and Neogene of Europe (see Bitner \& Cahuzac 2013; Dulai 2013, 2015; Bitner \& Müller 2015; Bitner \& Motchurova-Dekova 2016).

Order Craniida Waagen, 1885

Superfamily Cranioidea Menke, 1828

Family Craniidae Menke, 1828

\section{Genus Novocrania Lee \& Brunton, 2001}

Type species. - Patella anomala Müller, 1776, by original designation of Lee \& Brunton (1986, p. 150).

\section{Novocrania cf. anomala (Müller, 1776)}

Figure 2C-E

\footnotetext{
cf. 2013a Novocrania anomala (Müller). - Bitner et al., p. 584, fig. 2a-d (cum syn.).

cf. 2014 Novocrania anomala (Müller). - Emig, figs 2, 4, 5. cf. 2014a Novocrania anomala (Müller). - Robinson, fig. $5 \mathrm{c}-\mathrm{f}$.
} 


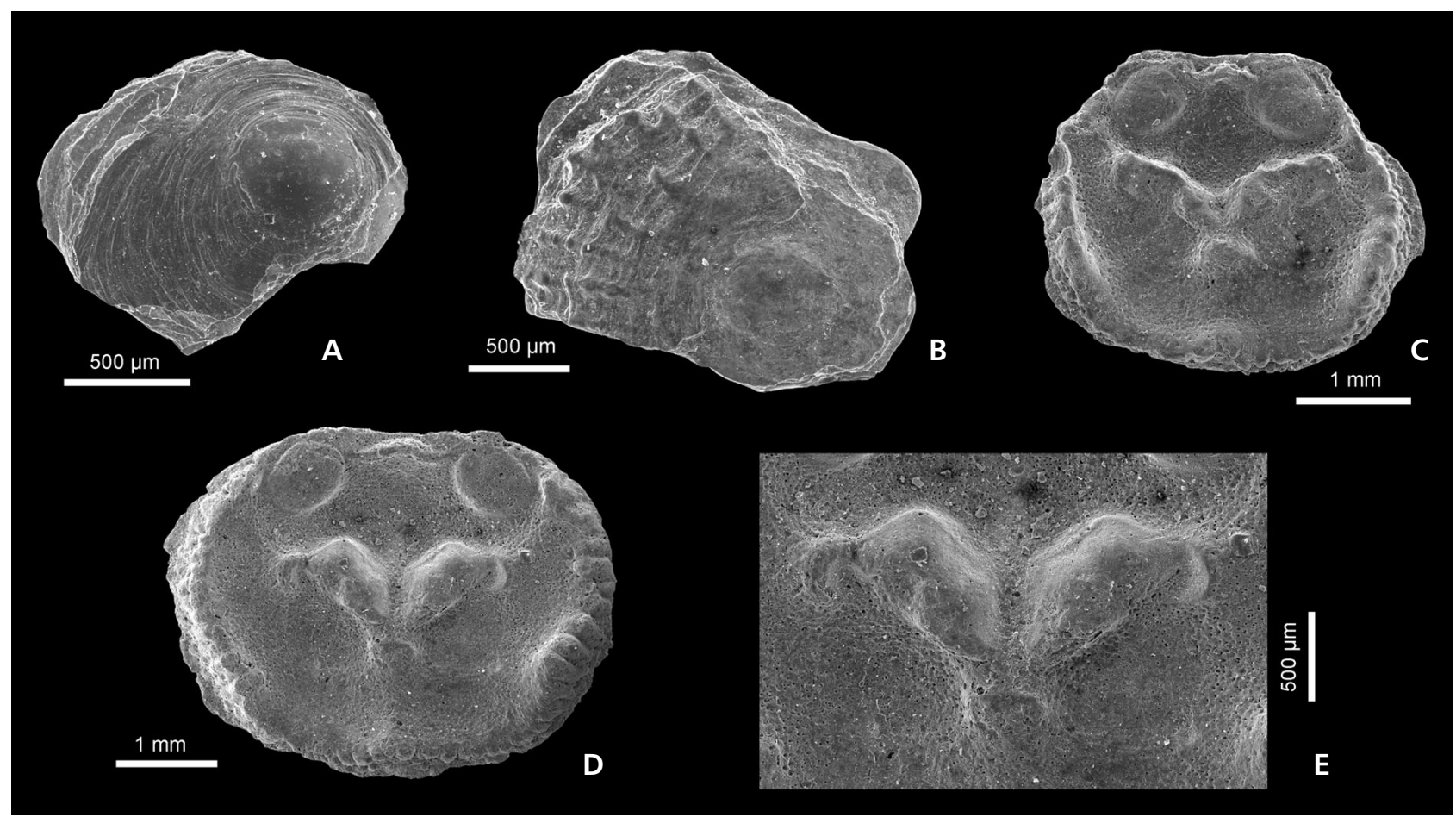

Figure 2. Brachiopods, Upper Eocene, Dnipropetrovsk, Ukraine. • A, B - Discradisca sp., dorsal valves; A - fragment of postlarval smooth shell, no. UDB 155; B - broken fragment with adult (neatic) ribbed shell, no. UDB $156 \cdot \bullet^{-}-\mathrm{E}-$ Novocrania cf. anomala (Müller, 1776), dorsal valves; C - interior view, no. UDB 157; D, E - interior view and enlargement (E) of anterior adductor muscle scars and support structure, no. UDB 158. All SEM.

cf. 2016 Novocrania anomala (Müller). - Bitner \& Motchurova-Dekova, p. 10, fig. 2c-g.

Material. - Six dorsal valves.

Remarks. - The specimens closely resemble Novocrania anomala (Müller, 1776), but because the ventral valves are missing and the material is limited we prefer to leave them in open nomenclature. The shell is small with maximum observed length $5.2 \mathrm{~mm}$, subcircular in outline, slightly conical with a subcentral to posteriorly directed apex. The outer surface is usually worn but irregular growth lines are visible. Posterior adductor muscle scars are subcircular, widely separated, lying near the margin. The anterior adductor muscle scars are oval to kidney-shaped, moderately elevated. Brachial retractors are small but distinct, separated from the adductor scars (Fig. 2E). Brachial protractor is indistinct. In a larger specimen mantle canals are observed in the anterior half of the valve.

Studying craniid musculature and its function Robinson $(2014 a)$ concluded that brachial retractor muscles are misnamed and an appropriate name should be support structure as given by Blochmann (1892). In addition, a new name has been proposed for brachial protractor muscles, small anterior muscles.

The separation of support structure from adductors used to be considered as an important distinguishable char- acter between Novocrania anomala and N. turbinata (Poli, 1795) (see Logan \& Long 2001, Kroh et al. 2008, Hiller 2011). According to Emig (2014) those differences fit within the intraspecific variability and both species are synonymous. However, in the opinion of Robinson (2015) $N$. anomala and $N$. turbinata are confirmed to be separate species based on morphology of the ventral valve. Interestingly, molecular studies seem to support the separation of those two species, nevertheless, the sequence analyses were made without close examination of shell morphology (Cohen et al. 2014).

The specimens described by Makarenko (1974) as a new craniid, Crania belokrysi are much larger than those from the Rybalsky Quarry, reaching up to $20 \mathrm{~mm}$. Based on the published illustrations and description it is difficult to determine if Makarenko's material also represents Novocrania anomala. Moreover, Makarenko (1974) wrongly attributed some of his specimens to ventral valves; all his illustrated specimens represent dorsal valves.

Occurrence. - Late Eocene (Priabonian) of Dnipropetrovsk, eastern Ukraine. Novocrania anomala was reported from the Upper Oligocene of France (Bitner et al. 2013a) and is common in the Miocene of Europe (Bitner \& Motchurova-Dekova 2016). Today this species lives in the Mediterranean Sea and the eastern North Atlantic from 3 to 1665 m (Logan 1979, Logan \& Long 2001). 


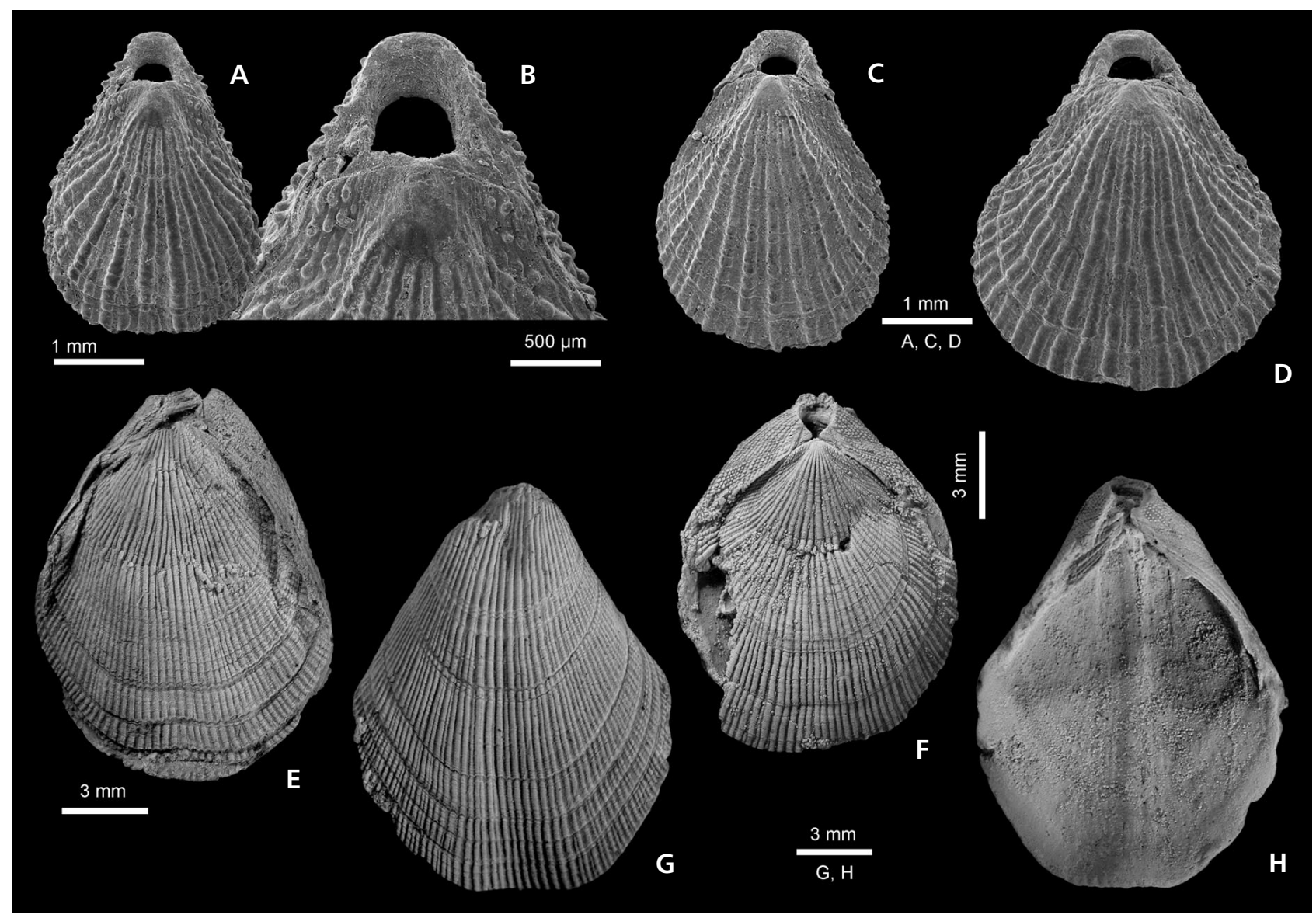

Figure 3. Terebratulina tenuistriata (Leymerie, 1846), Upper Eocene, Dnipropetrovsk, Ukraine. • A-F - dorsal views of complete specimens, and enlargement (B) of umbonal part; A, B - no. UDB 159; C - no. UDB 160; D - no. UDB 161; E - no. ZPAL Bp. 82/1; F - no. UDB 162. • G, H - exterior and interior views of ventral valve, no. ZPAL Bp.82/2. A-D SEM micrographs.

Order Terebratulida Waagen, 1883

Suborder Terebratulidina Waagen, 1883

Superfamily Cancellothyridoidea Thomson, 1926

Family Cancellothyrididae Thomson, 1926

Subfamily Cancellothyridinae Thomson, 1926

\section{Genus Terebratulina d'Orbigny, 1847}

Type species. - Anomia retusa Linnaeus, 1758, by subsequent designation of Brunton et al. (1967, p. 176).

\section{Terebratulina tenuistriata (Leymerie, 1846)}

Figure 3

1894 Terebratulina planicosta v. Koenen; Koenen, p. 1343, pl. 97, figs 7-10.

1894 Terebratulina tenuicosta v. Koenen; Koenen, p. 1346 , pl. 97 , fig. 6 .

1894 Terebratulina asperula v. Koenen; Koenen, p. 1347, pl. 97, figs $2-5$.

1975 Terebratulina parisiensis (Deshayes). - Zelinskaya, p. 111 , pl. 11, fig. 7 .
1975 Terebratulina putoni (Baudon). - Zelinskaya, p. 112 , pl. 12 , figs 8,9 .

1975 Terebratulina tenuilineata (Baudon). - Zelinskaya, p. 113, pl. 11, fig. 8 .

1975 Terebratulina asperula Koenen. - Zelinskaya, p. 114 , pl. 12, figs 1,2 .

1975 Terebratulina tenuicosta Koenen. - Zelinskaya, p. 115 , pl. 12 , fig. 3 .

1975 Terebratulina polydichotoma Mayer. - Zelinskaya, p. 118 , pl. 13, figs 3,4 .

1975 Terebratulina planicosta Koenen. - Zelinskaya, p. 122 , pl. 13, figs 1,2 .

2000 Terebratulina tenuistriata (Leymerie). - Bitner, p. 118, figs 2, 3, 4a-f, 5a-g (cum syn.).

2005 Terebratulina sp. cf. T. tenuistriata (Leymerie). Bitner \& Dieni, p. 108, fig. 6a.

2008 Terebratulina tenuistriata (Leymerie). - Bitner \& Dulai, p. 33, fig. 4.1-8.

2009 Terebratulina tenuistriata (Leymerie). - Bitner \& Boukhary, p. 396, fig. 3a-f.

2010 Terebratulina tenuistriata (Leymerie). - Dulai et al., p. 185 , pl. 3 , figs $1-11$. 


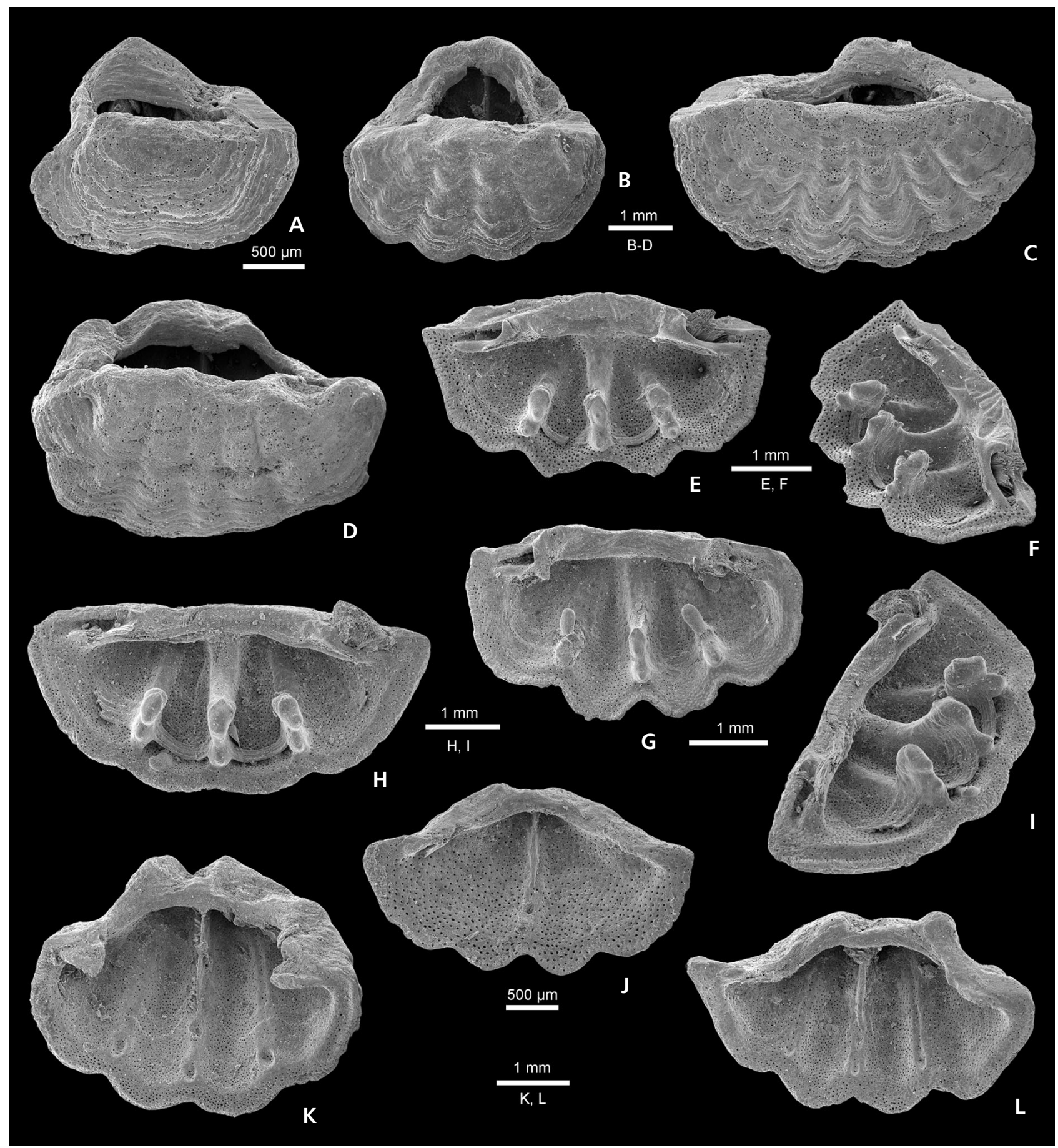

Figure 4. Megathiris detruncata (Gmelin, 1791), Upper Eocene, Dnipropetrovsk, Ukraine. • A-D - dorsal views of complete specimens; A - juvenile specimen, no. UDB 163; B - no. UDB 164; C - no. UDB 165; D - no. UDB 166. • E-I - dorsal valves, visible three septa; E, F - interior and oblique views, no. UDB 167; G - interior view, no. UDB 168; H, I - interior and oblique views, no. UDB 169 . $\bullet$ J-L - interior of ventral valves; J - no. UDB 170 ; $\mathrm{K}-$ no. UDB 171; L - no. UDB 172. All SEM.

2011 Terebratulina tenuistriata (Leymerie). - Bitner et al., p. 122, fig. 3a-c.

2011 Terebratulina tenuistriata (Leymerie). - Dulai, p. 299 , fig. 4 .
2012 Terebratulina tenuistriata (Leymerie). - Bitner \& Boukhary, fig. 2c, d.

2015 Terebratulina tenuistriata (Leymerie). - Bitner \& Müller, p. 677, fig. 4. 
2016 Terebratulina tenuistriata (Leymerie). - Bitner et al., p. 3, figs 2.4-6.

Material. - 82 articulated specimens plus 9 ventral and 6 dorsal valves.

Remarks. - The species Terebratulina tenuistriata has been reported from the Eocene of Ukraine, but under several different names (Zelinskaya 1975). Here this species is relatively common. In shell outline and ornamentation the specimens closely resemble those from other localities (e.g. Bitner 2000; Bitner et al. 2011, 2016; Bitner \& Müller 2015). The shell is of medium size (maximum observed length $=16.2 \mathrm{~mm}$ ), elongate oval and biconvex. Its surface is covered with numerous, fine ribs.

Occurrence. - Late Eocene (Priabonian) of Dnipropetrovsk, Ukraine. This species is well known in the Eocene of Europe, and is also reported from Egypt and the United Arab Emirates (see fig. 3 in Bitner \& Boukhary 2012). Recently it was recognized in the Lower Oligocene of Central Germany (Bitner \& Müller 2015).

Suborder Terebratellidina Muir-Wood, 1955

Superfamily Megathyridoidea Dall, 1870

Family Megathyrididae Dall, 1870

\section{Genus Megathiris d'Orbigny, 1847}

Type species. - Anomia detruncata Gmelin, 1791, by subsequent designation of Dall (1920, p. 331).

\section{Megathiris detruncata (Gmelin, 1791)}

Figure 4

1864 Argiope multicostata n. spec.; Bosquet, p. 3, figs $1-5$.

1894 Argiope multicostata Bosquet. - von Koenen, p. 1357, pl. 98, figs 16-17.

1990 Megathiris detruncata (Gmelin). - Bitner, p. 135, text-figs 3, 4, pl. 3, figs 1-8, pl. 6, figs 1-7 (cum syn.).

1990 Megathiris detruncata (Gmelin). - Popiel-Barczyk \& Barczyk, p.175, text-figs 10, 11, pl. 6, figs 6-11, pl. 7, figs 1-13.

2003 Megathiris detruncata (Gmelin). - Bitner \& Moissette, p. 473, fig. $6 \mathrm{~g}$, h.

2004 Megathiris detruncata (Gmelin). - Bitner \& Dulai, p. 74, pl. 3, figs 11-15.

2007 Megathiris detruncata (Gmelin). - Dulai, p. 2, fig. 2.1-2.

2008 Megathiris detruncata (Gmelin). - Bitner \& Dulai, p. 35 , fig. $5.1-4$.
2009 Megathiris detruncata (Gmelin). - Bitner \& Schneider, p. 127, fig. 6a-c.

2010 Megathiris detruncata (Gmelin). - Dulai, p. 26, pl. 3, fig. 1a, b.

2010 Megathiris detruncata (Gmelin). - Dulai et al., p. 186, pl. 2, fig. 4.

2011 Megathiris detruncata (Gmelin). - Dulai, p. 305, fig. $8 \mathrm{a}, \mathrm{b}$.

2011 Megathiris cf. detruncata (Gmelin). - Müller, p. 20, pl. 3, figs 11-13.

2012 Megathiris detruncata (Gmelin). - Zágoršek et al., p. 27, fig. 6d, e.

2013a Megathiris detruncata (Gmelin). - Bitner et al., p. 586, fig. 3a-m.

2013b Megathiris detruncata (Gmelin). - Bitner et al., p. 83 , fig. $3 \mathrm{j}-1$.

2016 Megathiris detruncata (Gmelin). - Bitner \& Motchurova-Dekova, p. 10, fig. 3a-1.

Material. - 47 articulated specimens, 70 ventral valves, 153 dorsal valves.

Remarks. - This species is one of the most common in the investigated assemblage and this is the first record of any representative of the genus Megathiris from the Eocene of Ukraine. Specimens assigned to Megathiris by Zelinskaya (1962, 1975) undoubtedly belong to Argyrotheca (see below).

Megathiris detruncata is characterized by its small, transversely elongate to subpentagonal shell ornamented by a few broad, rounded ribs. The foramen is large, subtriangular. This species can be easily distinguishable from other megathyridids by the presence of three septa on the interior of the dorsal valve.

Occurrence. - Late Eocene (Priabonian) of Dnipropetrovsk, Ukraine. Megathiris detruncata has a long stratigraphical range from the Eocene to the Holocene. Today it lives in the Mediterranean Sea and the north-eastern Atlantic with a depth range from 5 to 896 m (Logan 2007).

\section{Genus Argyrotheca Dall, 1900}

Type species. - Terebratula cuneata Risso, 1826, by original designation of Dall (1900, p. 44).

\section{Argyrotheca lunula (von Koenen, 1894)}

Figure 5

1894 Argiope lunula v. Koenen; Koenen, p. 1360, pl. 98, figs 6-10.

1894 Argiope lunula var. percostata v. Koenen; Koenen, p. 1361, pl. 98, figs 11-13. 


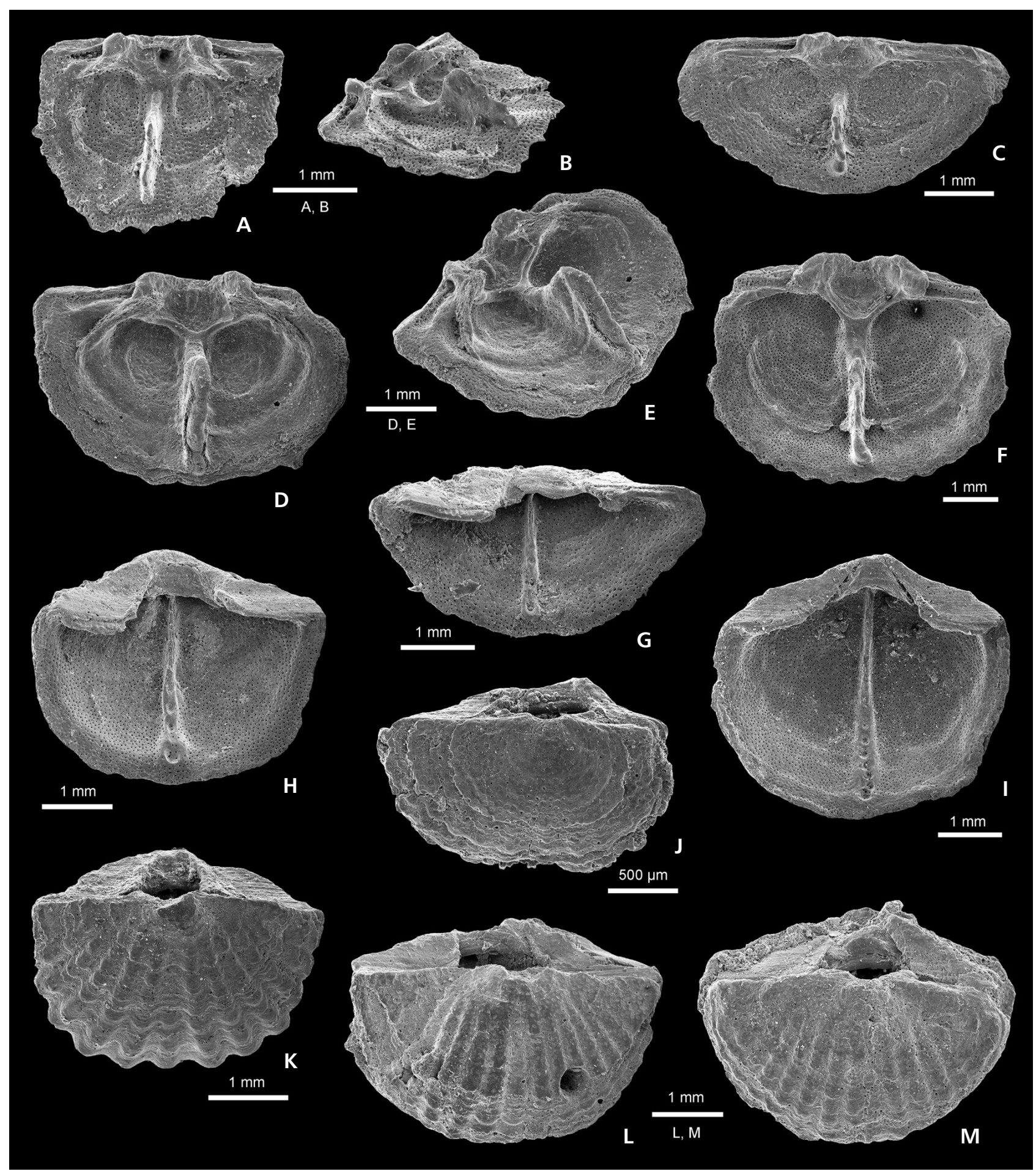

Figure 5. Argyrotheca lunula (von Koenen, 1894), Upper Eocene, Dnipropetrovsk, Ukraine. • A-F - dorsal valves; A, B - interior and oblique views, no. UDB 173; C - interior view, no. UDB 174; D, E - interior and oblique views, no. UDB 175; F-interior view, no. UDB $176 \cdot \bullet \mathrm{G}-\mathrm{I}-$ interior of ventral valves; G - no. UDB 177; H - no. UDB 178; I - no. UDB 179. • J-M - dorsal views of complete specimens; J - young individual, no. UDB 180; K - no. UDB $181 ; \mathrm{L}$ - no. UDB 182; M - no. UDB 183. All SEM.

1962 Megathyris lunula percostata (Koenen). - Zelinskaya, p. 109, text-fig. 2, pl. 6, figs 9-11.
1975 Megathyris lunula percostata (Koenen). - Zelinskaya, p. 124, pl. 16, figs 6-12. 


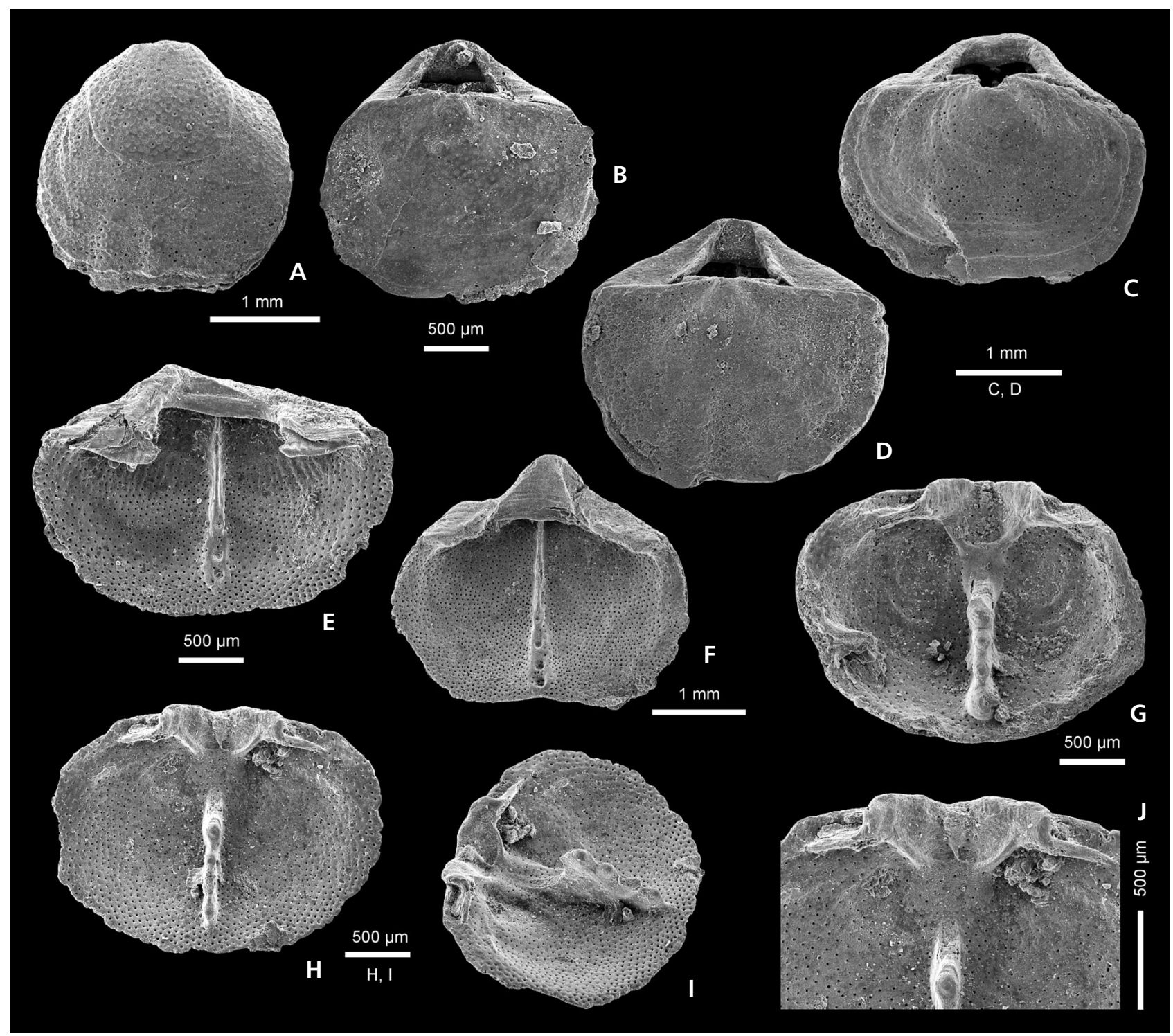

Figure 6. Argyrotheca megapora Zelinskaya, 1975, Upper Eocene, Dnipropetrovsk, Ukraine. • A - ventral view of complete specimen, no. UDB 184. -B-D - dorsal views of complete specimens; B - no. UDB 185; C - no. UDB 186; D - no. UDB 187. E, F - interior of ventral valves; E - no. UDB 188; $\mathrm{F}-$ no. UDB $189 . \cdot \mathrm{G}-\mathrm{J}$ - dorsal valves; $\mathrm{G}$ - interior view, no. 190; H-J - interior and oblique views, and enlargement of posterior part to show details of cardinalia, no. UDB 191. All SEM.

1987 Argyrotheca lunula (Koenen). - Popiel-Barczyk \& Barczyk, p. 98, text-fig. 5, pl. 2, figs 1-3.

Material. - 61 articulated specimens, 45 ventral and 113 dorsal valves.

Description. - Shell small (maximum observed length $4.9 \mathrm{~mm}$ ), thick, variable in outline from transversely elongate to subrectangular with maximum width at hinge line, ventribiconvex. Shell surface with up to 15 rounded ribs; in juvenile specimens delicate ribs visible only on the anterior part (Fig. 5J). Foramen large, triangular, hypothyrid, flanked by narrow deltidial plates.
Lateral commissures straight, anterior commissure rectimarginate.

Ventral valve interior with long, narrow teeth lying parallel to the hinge margin. Pedicle collar well-developed, supported by a septum. Dorsal valve interior with narrow but massive inner socket ridges. Cardinal process distinct. Hinge plates attached to the septum forming a broad trough. Crura very short. Loop attached to valve floor and anteriorly to septum. Septum high, triangular in profile; serrations present in young specimens, in adult they are overgrown (Fig. 5D, E).

Remarks. - This species, originally described from West 
Germany (von Koenen 1894), was reported from the Eocene of Ukraine by Zelinskaya (1962, 1975), who wrongly assigned it to the genus Megathiris, a brachiopod characterized by the presence of three septa on the dorsal valve, a feature observed neither in the original material from Germany (von Koenen 1894) nor in the specimens from Ukraine (Zelinskaya 1975, pl. 14, figs 9, 10). The lateral ridges on the ventral valve reported by Zelinskaya (1962, 1975) are not diagnostic characters for Megathiris.

Argyrotheca lunula is one of the most common species in the material under study. In shell outline and ornamentation the specimens from the Rybalsky Quarry are consistent with those hitherto described, differing only in larger size.

Occurrence. - Late Eocene (Priabonian) of Dnipropetrovsk, Ukraine. Apart from Ukraine this species was also recorded from the Upper Eocene/Lower Oligocene of West Germany (von Koenen 1894) and Upper Eocene of southern Poland (Popiel-Barczyk \& Barczyk 1987).

\section{Argyrotheca megapora Zelinskaya, 1975}

Figure 6

1975 Argyrotheca megapora Zelinskaya; Zelinskaya, p. 132 , pl. 16, fig. 1.

Material. - 38 articulated specimens, 14 ventral and 26 dorsal valves.

Description. - Shell thin, small, weakly biconvex, smooth or covered with poorly defined ribs. Hinge line straight, long. Foramen large, triangular, hypothyrid, bordered by raised deltidial plates. Pedicle collar wide, supported by a slender septum. Dorsal valve with narrow but thick inner socket ridges and prominent cardinal process. Hinge plates attached to valve floor. Loop not preserved. Dorsal median septum high, triangular in profile with 4 serrations.

Remarks. - This species is relatively common in the Dnipropetrovsk assemblage. Externally, in outline and poorly defined ribs it resembles somewhat Joania cordata (Risso, 1826) but differs strongly internally by the lack of marginal tubercles (Logan 1979; Bitner 1990, 1993; Bitner et al. 2013a; Bitner \& Motchurova 2016).

Occurrence. - Late Eocene (Priabonian) of Dnipropetrovsk, Ukraine. Argyrotheca megapora seems to be endemic to the Eocene of Ukraine.

\section{Genus Bronnothyris Popiel-Barczyk \& Smirnova, 1978}

Type species. - Terebratula bronnii Roemer, 1841 by original designation of Popiel-Barczyk \& Smirnova (1978, p. 41).
Bronnothyris danaperensis sp. nov. Figure 7

Types. - Holotype no. UDB 193 figured in Fig. 7D, paratypes no. UDB 194-201 figured in Fig. 7B, C, E-N.

Type locality. - Rybalsky Quarry, Dnipropetrovsk, eastern Ukraine.

Type horizon. - Priabonian, Late Eocene.

Etymology. - After Danaper, the Latin name of the Dnieper River.

Diagnosis. - Bronnothyris with smooth surface and hinge line equal to maximum width; foramen large, hypothyrid with narrow pedicle collar; hinge plates fused forming a broad, coherent platform; dorsal median septum high with short septal flanges.

Material. - 24 articulated specimens, 38 ventral and 148 dorsal valves.

Measurements. - in mm.

$\begin{array}{lrrc}\text { Specimen } & \text { Length } & \text { Width } & \text { Thickness } \\ \text { Holotype UDB 193 } & 3.7 & 5.7 & 2.0 \\ \text { Paratype UDB 194 } & 2.4 & 3.1 & 2.1 \\ \text { Paratype UDB 195 } & 2.6 & 4.4 & 1.9\end{array}$

Description. - Shell small, thick, subrectangular to transversely oval in outline, wider than long, ventribiconvex. Shell surface smooth with numerous, distinct growth lines. Anterior commissure rectimarginate, lateral commissures straight. Beak low, suberect with sharp beak ridges. Interarea narrow transversely striated. Beak and area can be eroded, suggesting a short pedicle. Foramen, substriangular, hypothyrid, bordered by two narrow deltidial plates, often poorly defined. Hinge line straight, equal to maximum width.

Ventral valve interior with short but wide teeth parallel to hinge margin (Fig. $7 \mathrm{~N})$. Sometimes teeth are strongly reduced (Fig. 7L). Pedicle collar narrow, supported by a median septum extending to about mid-valve. Shallow depressions to accommodate serrations of dorsal septum visible.

Dorsal valve interior with short, widely divergent socket ridges occupying most of valve width. Rough surface between ridges most probably served as cardinal process. Outer and inner hinge plates very broad, fused to form a single coherent platform. Crura very short or absent. Crural processes medianly directed, massive. Loop attached to valve floor and septum (Fig. 7F-H). Short septal flanges extend ventrally from the septum (Fig. 7H, K). Septum triangular in profile, high, with 3 serrations. 
Remarks. - The genus Bronnothyris was established based on the presence of septal flanges extending from the dorsal septum, the feature not observed in other megathyridids (see Popiel-Barczyk \& Smirnova 1978, Bitner \& Kroh 2011). This feature is also displayed in the specimens under study, supporting their attribution to Bronnothyris.

In its fused hinge plates forming a single, broad platform the newly established species, Bronnothyris danaparensis sp. nov. is most similar to the Early Oligocene B. subradiata (Sandberger, 1862) from the Mainz Basin, differing, however, externally; B. subradiata has a high beak and shell surface covered with up to 10 ribs (Bitner \& Kroh 2011). The fused hinge plates are also observed in the Late Cretaceous species, B. coniuncta (Steinich, 1965), however, in that species the plates are much narrower and it differs in having strongly transversely elongate outline and ribbed surface (Steinich 1965).

The newly described species also displays similarities to Argyrotheca wansinensis Vincent, 1923 from the Upper Paleocene of Belgium (Vincent 1923), however, insufficient description and illustrations as well a major stratigraphical and geographical gap prevent any further conclusions (see also discussion in Bitner \& Kroh 2011).

Systerova (2014) also recognized the genus Bronnothyris in the material from the Rybalsky Quarry. However, the three species proposed in this paper should be treated as nomen nudum according to the ICZN (1999) rules. There are no descriptions, insufficient illustrations, and no designation of holotypes. Additionally, the species were presented in the local conference materials as nomen provisorium, a form that does not exist in the ICZN. There is no doubt that all three Systerova's (2014) species are conspecific with $B$. danaparensis sp. nov. fitting within the intraspecific variability.

Occurrence. - Late Eocene (Priabonian) of Dnipropetrovsk, Ukraine.

\section{Genus Joania Álvarez, Brunton \& Long, 2008}

Type species. - Terebratula cordata Risso, 1826 by original designation of Álvarez et al. (2008, p. 400).

\section{Joania ukrainica sp. nov.}

Figure 8

Types. - Holotype no. UDB 203 figured in Fig. 8B-F, paratype no. UDB 202 figured in Fig. 8A.
Type locality. - Rybalsky Quarry, Dnipropetrovsk, eastern Ukraine.

Type horizon. - Priabonian, Late Eocene.

Etymology. - After Ukraine, the country of origin. Gender feminine.

Diagnosis. - Small Joania with wide, rounded ribs up to 12 ; teeth wide, parallel to hinge margin, cardinal process distinct.

Material. - 3 articulated specimens, 2 ventral and one dorsal valves.

Measurements. - in mm.

$\begin{array}{lrrc}\text { Specimen } & \text { Length } & \text { Width } & \text { Thickness } \\ \text { Holotype UDB 203 } & 2.4 & 2.7 & 1.4 \\ \text { Paratype UDB 202 } & 2.2 & 2.6 & 1.1\end{array}$

Description. - Shell small (maximum observed length $2.4 \mathrm{~mm}$ ), thin, wider than long, subrectangular in outline, weakly biconvex. Shell surface with 10 to 12 single, broad, rounded ribs with narrow grooves between them; median rib thinner and shorter. Growth lines indistinct. Hinge line wide, straight to slightly curved. Beak erect with sharp beak ridges and narrow interarea. Foramen large, triangular, hypothyrid, bordered by two narrow, disjunct deltidial plates. Lateral commissures straight. Anterior commissure rectimarginate with a very shallow, median sulcus in both valves.

Ventral valve interior with wide, short teeth parallel to hinge margin. Pedicle collar wide, supported by a slender septum extending to about mid valve. Ovoid depressions to accommodate dorsal septum serrations present.

Dorsal valve interior with well-developed, narrow inner socket ridges. Hinge plates fused with valve floor. Cardinal process distinct. Crura very short; crural processes relatively long, directed medianly. Descending branches posteriorly curved, united quickly with valve floor; loop emerges anteriorly to attach to a dorsal median septum. Septum high, triangular in profile, sloping towards the anterior margin with 5 serrations. Elongated tubercles on inner margin of both valves.

Remarks. - The presence of marginal tubercles, an important diagnostic character of the genus Joania (see Álvarez

Figure 7. Bronnothyris danaperensis sp. nov., Upper Eocene, Dnipropetrovsk, Ukraine. - A-D - dorsal views of complete specimens; A - juveline specimen, no. UDB 192; B, C - paratypes, no. UDB 194-195; D - holotype, no. UDB 193. • E-K - dorsal valves, paratypes; E - interior view, no. UDB 


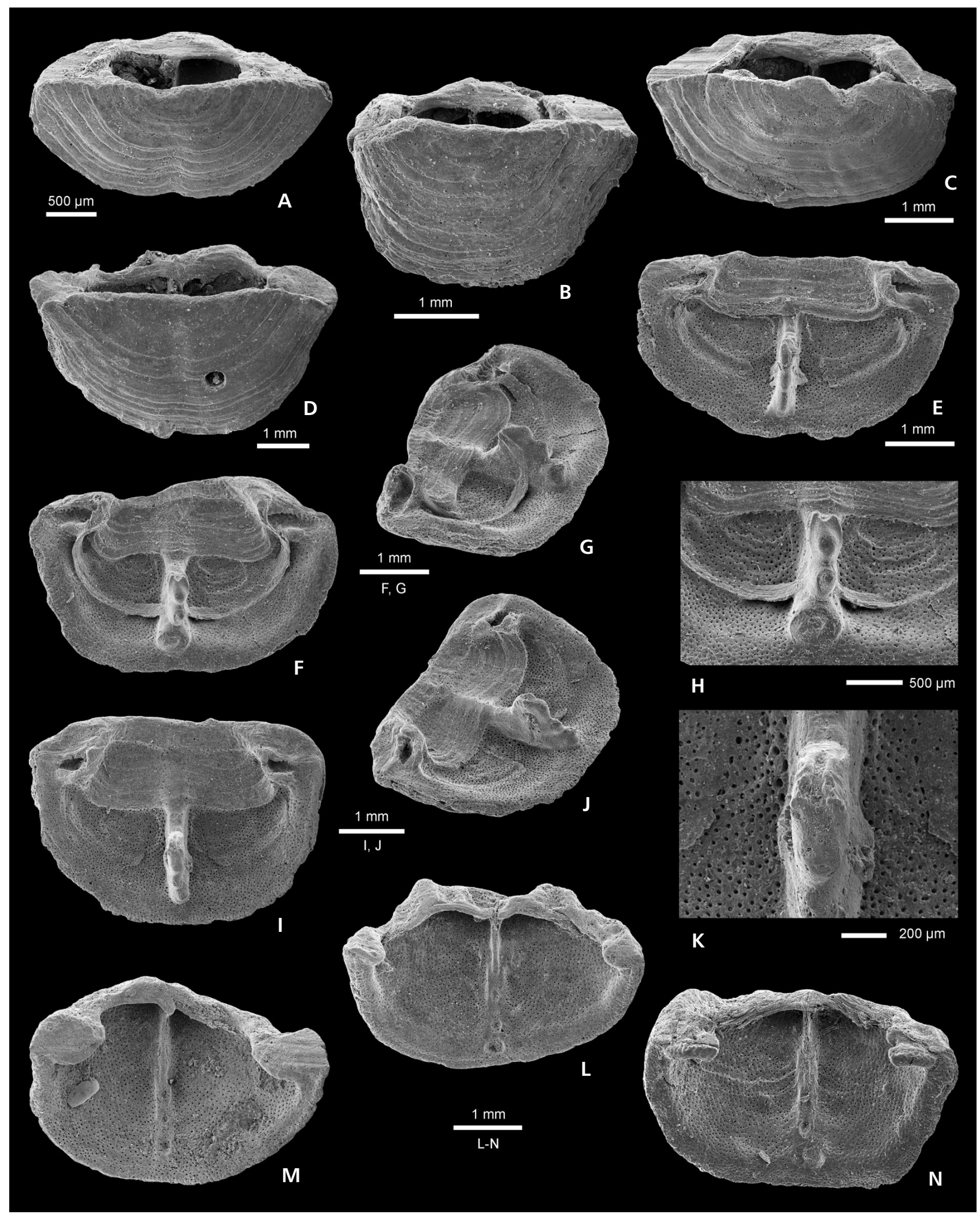

196; F-H - interior and oblique views, and enlargement tilted (H) of median septum to show extended septal flanges of dorsal valves, no. UDB 197; I-K, interior and oblique views, and enlargement $(\mathrm{K})$ of median septum with extended septal flanges, no. UDB $198 ; \bullet \mathrm{L}-\mathrm{N}-$ interior of ventral valves, paratypes; L - no. UDB 199; M - no. UDB 200; N - no. UDB 201. All SEM. 


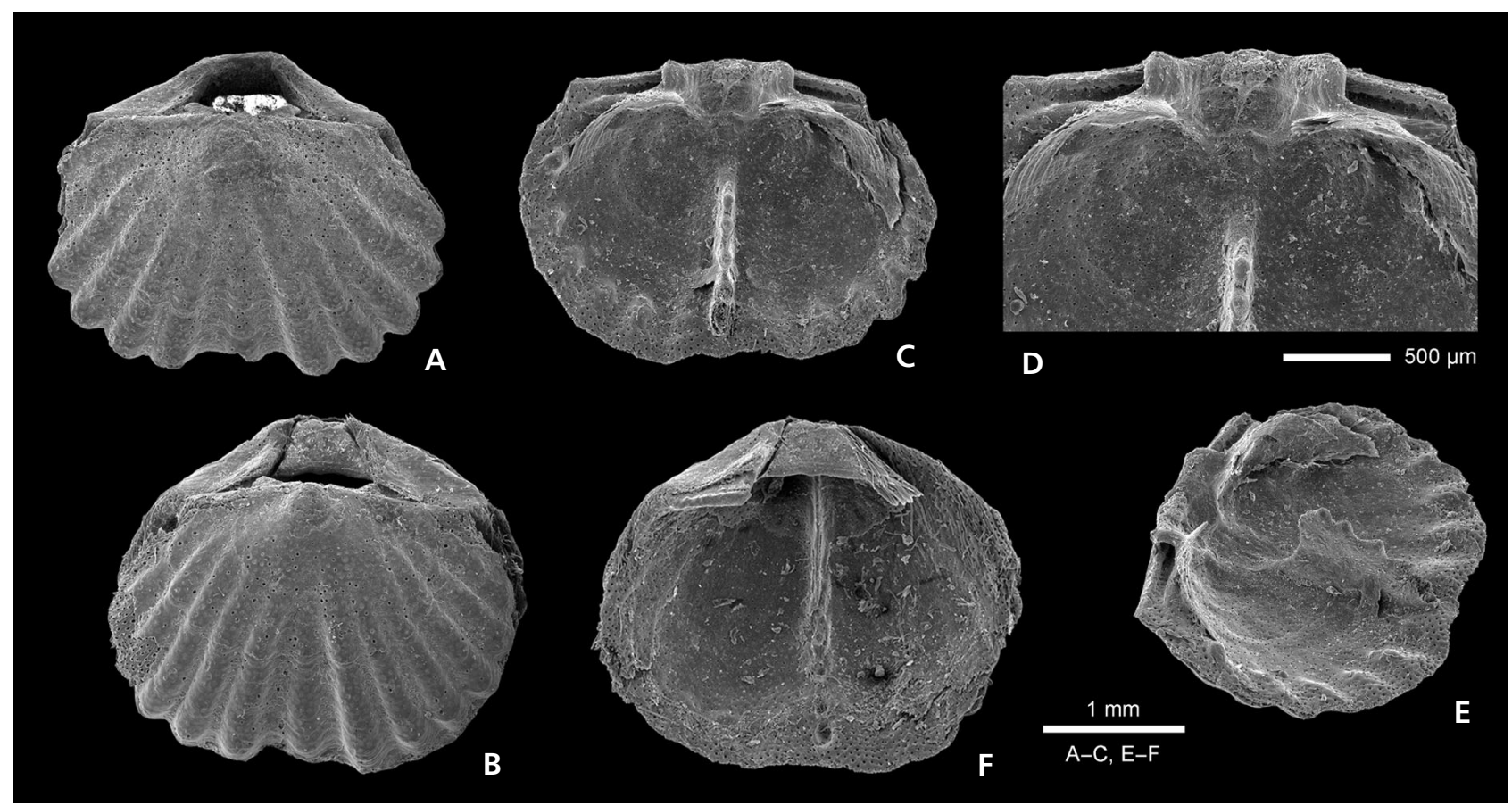

Figure 8. Joania ukrainica sp. nov., Upper Eocene, Dnipropetrovsk, Ukraine. • A - dorsal view of complete specimen, paratype, no. UDB 202. - B-F- complete specimen, holotype, no. UDB 203; B - dorsal view; C-E - interior and oblique (E) views of dorsal valve, and enlargement (D) of posterior part to show details of cardinalia; F - interior of ventral valve. All SEM.

et al. 2008), indicates attribution to this genus. By its ornamentation Joania ukrainica sp. nov. is easily distinguishable from the type species $J$. cordata (Risso, 1826) whose shell is subtriangular in outline and smooth or covered with imperceptible costae (Logan 1979; Bitner 1990, 1993; Bitner \& Kaim 2004; Álvarez et al. 2008; Bitner \& Motchurova 2016).

Although similar in size and outline, the specimens from Dnipropetrovsk differ markedly from the Late Oligocene species from the Aquitaine Basin, Joania peyrerensis Bitner, Lozouet \& Cahuzac, 2013 in character of ribs; in J. peyrerensis ribs are fewer, narrow, with large spaces between them (Bitner et al. 2013a). Also in $J$. ukrainica teeth are wide and short, while those in $J$. peyrerensis form a small triangular plate.

Another ribbed Joania species, J. ageriana (Taddei Ruggiero, 1993) from the Lower Pleistocene of Italy shows significant differences in shell size and nature of ribbing. It is much larger than the Eocene species, reaching $7 \mathrm{~mm}$ in length, and ornamented by numerous (up to 18), fine ribs (Taddei Ruggiero 1993).

Occurrence. - Late Eocene (Priabonian) of Dnipropetrovsk, Ukraine.

Superfamily Platidioidea Thomson, 1927

Family Platidiidae Thomson, 1927

Subfamily Platidiinae Thomson, 1927

\section{Genus Platidia Costa, 1852}

Type species. - Orthis anomioides Scacchi \& Philippi, 1844, by original designation of Costa (1852, p. 47).

\section{Platidia sp.}

Figure 9A

Material. - 3 articulated specimens, one broken.

Remarks. - Platidia is rare in the material under study. The specimens are small, hardly exceeding $2 \mathrm{~mm}$. Their shell is smooth, subcircular in outline with a short, straight hinge line and a large, amphithyrid foramen.

In size and outline the specimens from the Rybalsky Quarry are similar to those described by Dulai (2011) as Platidia anomioides from the Upper Eocene of Austria. Our material, however, precludes any assignment at species level.

Occurrence. - Late Eocene (Priabonian) of Dnipropetrovsk, Ukraine. Platidia is very common in the Miocene of the Central Paratethys (Bitner 1990, Popiel-Barczyk \& Barczyk 1990, Bitner \& Dulai 2004, Bitner et al. 2013b, Bitner \& Motchurova-Dekova 2016). It is also widespread in modern oceans, having a very wide depth range from $8 \mathrm{~m}$ to more than $2000 \mathrm{~m}$ (Logan 2007). 


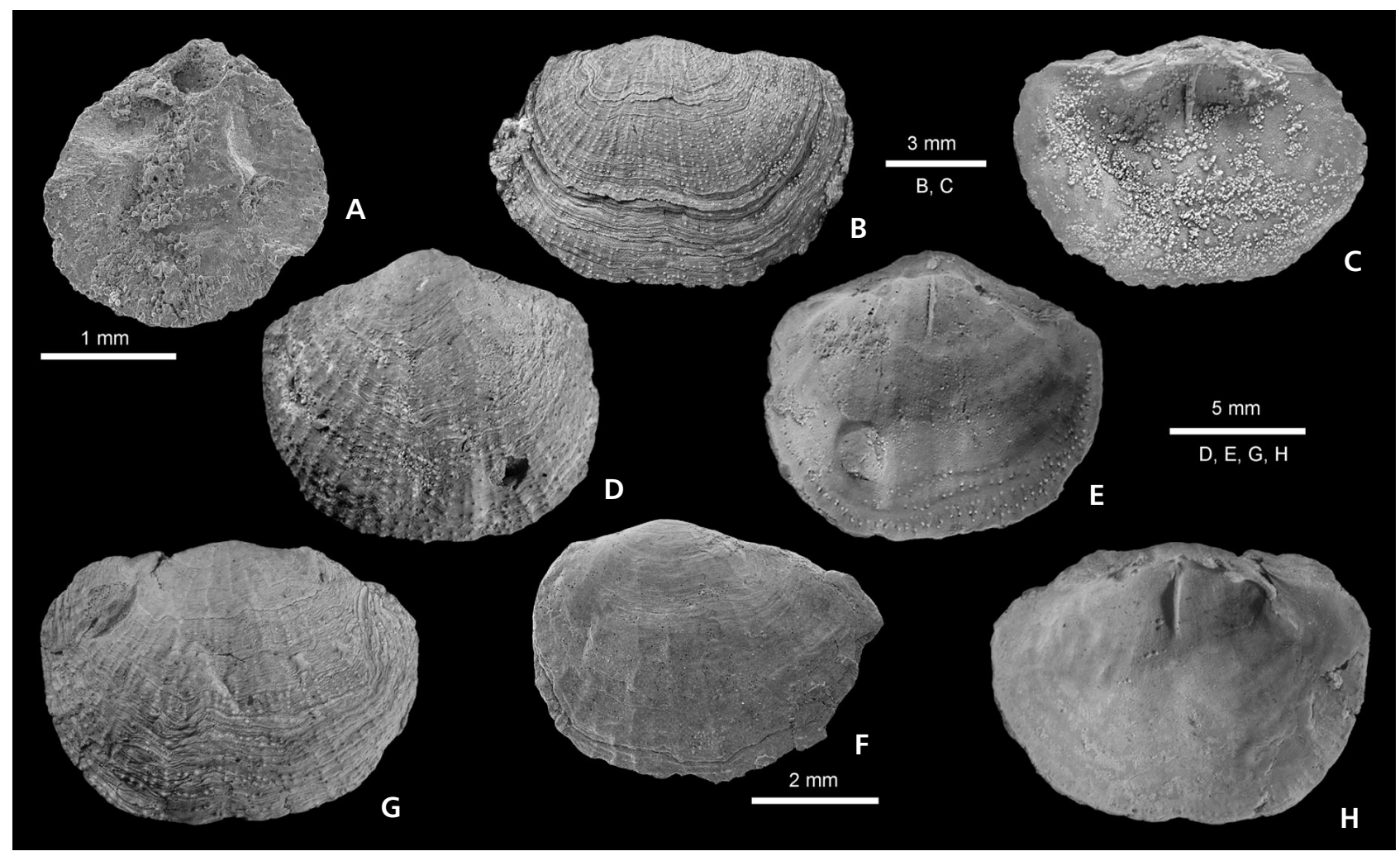

Figure 9. Brachiopods Upper Eocene, Dnipropetrovsk, Ukraine. • A - Platidia sp., dorsal view of complete specimen, SEM, no. UDB 204. - B-H - Megerlia sp., ventral valves; B, C - external and interior views, no. UDB 205; D, E - exterior and interior views, no. ZPAL Bp.82/3; F- exterior view, SEM, no. UDB 206; G, H - exterior and interior views, no. ZPAL Bp.82/4.

Superfamily Kraussinoidea Dall, 1870

Family Kraussinidae Dall, 1870

Subfamily Megerliinae Hiller, MacKinnon \& Nielsen, 2008

\section{Genus Megerlia King, 1850}

Type species. - Anomia truncata Linnaeus, 1767, by the original designation of King (1850, p. 145).

\section{Megerlia sp.}

Figure 9B-H

Material. - Nine ventral valves.

Remarks. - Megerlia is rare in the investigated material and represented only by ventral valves. The shell is transversely oval, wider than long, reaching up to $11 \mathrm{~mm}$ length and $14 \mathrm{~mm}$ in width. The shell surface is covered with numerous, fine, nodulose ribs; concentric growth lines are distinct. The foramen is large with a narrow pedicle collar. The teeth are widely separated, without dental plates. A short, low septum is present in the posterior part.

All the characters mentioned above support attribution to the genus Megerlia, however, missing dorsal valves prevent attribution to species level and/or description of a new spe- cies. This is the first record of this genus from the Eocene, extending its stratigraphical range. So far the oldest occurrence of Megerlia has been from the Lower Oligocene of Germany (Müller 2011). The specimens described by von Koenen (1894) as Argiope? squamulosa most probably represent the genus Megerlia based on description and illustrations.

Occurrence. - Late Eocene (Priabonian) of Dnipropetrovsk, Ukraine.

Order Thecideida Elliott, 1958

Superfamily Thecideoidea Gray, 1840

Family Thecideidae Gray, 1840

Subfamily Lacazellinae Backhaus, 1959

\section{Genus Lacazella Munier-Chalmas, 1880}

Type species. - Thecidea mediterranea Risso, 1826, by original designation of Munier-Chalmas (1880, p. 279).

\section{Lacazella mediterranea (Risso, 1826)}

Figure 10

1894 Thecidium mediterraneum L. var. Lattorfense Davidson. - v. Koenen, p. 1364, pl. 97, figs 11-16. 
1970 Lacazella mediterranea (Risso). - Pajaud, p. 128, text-figs 50, 52, pl. 1, fig. 4, pl. 5, fig. 4, pl. 7, fig. 3, pl. 10, figs 1-6; pl. 11, fig. 3, pl. 12, fig. 2, pl. 16 (cum syn.).

1977 Lacazella lattorfense (Davidson). - Zelinskaya, p. 687 , text-fig. 1.1-5.

1979 Lacazella mediterranea (Risso). - Logan, p. 73, text-fig. 22, pl. 10, figs 1-8.

1987 Lacazella mediterranea (Risso). - Popiel-Barczyk \& Barczyk, p. 101, pl. 3, figs 3-11.

2005 Lacazella mediterranea (Risso). - Bitner \& Dieni, p. 109 , fig. $4 \mathrm{i}-\mathrm{k}$.

2008 Lacazella mediterranea (Risso). - Bitner \& Dulai, p. 40 , fig. $5.7-8$.

2010 Lacazella mediterranea (Risso). - Dulai, p. 28, pl. 3, fig. 3a, b.

2011 Lacazella mediterranea (Risso). - Müller, p. 20, pl. 3, fig. 14.

2012 Lakazella sp. - Systerova, fig. 1.

2013a Lacazella mediterranea (Risso). - Bitner et al., p. 595 , fig. $9 \mathrm{a}-1$.

Material. - 11 articulated specimens, 64 ventral and 379 dorsal valves.

Remarks. -This is the second record of Lacazella meditteranea from the Eocene of Ukraine (Zelinskaya 1977). This species is the commonest brachiopod in the assemblage from the Rybalsky Quarry. Its shell is small (maximum observed length $5.2 \mathrm{~mm}$ ), subtriangular in outline, with a strongly convex ventral valve and almost flat dorsal one. The beak is high, without foramen; the delthyrium is closed by a convex, triangular pseudodeltidium for which Logan \& Baker (2013) propose the name rugideltidium. The hemispondylium, supported by a small median septum, projects as two prominent prongs (Fig. 10I, G). A trifurcating dorsal median septum is characteristic for Lacazella (Fig. 10A-E). Margins of both valves are papillose.

Occurrence. - Lacazella mediterranea has a very wide stratigraphical range, being first noted from the Upper Palaeocene of Spain (Pajaud \& Plaziat 1972). In the Eocene this species is widespread in Europe (see Bitner \& Dieni 2005, Bitner \& Dulai 2008). Today L. mediterranea is considered as neoendemic (Logan et al. 2004), being known from the western part of the Mediterranean Sea at depths of 1-110 m (Logan 2007, Emig 2016).

\section{Palaeoecological remarks}

The detrital sands cropping out in the Rybalsky Quarry at Dnipropetrovsk contain an abundant and diverse Late Eocene fauna of corals, sponges, bivalves, gastropods, brachiopods, bryozoans and fish otoliths. The brachiopods are rich in specimens but of low diversity; eleven species have been identified. Apart from two species cemented to the substrate by the ventral valve, Novocrania cf. anomala and Lacazella mediterranea, all species have a functional pedicle opening and lived attached by a pedicle to a hard substrate. Dominance of megathyridids and thecideides indicate a warm, shallow-water environment (Logan 1977, 1979; Álvarez et al. 2005) which is supported by the associated molluscs and fish otoliths (Müller \& Rozenberg 2003, Amitrov 2008).

\section{Drilling predation}

Gastropod drilling predation on invertebrate shells, including brachiopods is of great interest and has been subject of many reports. However, in the Cenozoic drilling predation on brachiopods was only occasionally intense (e.g. Baumiller \& Bitner 2004; Harper 2005, 2011; Baumiller et al. 2006; Tuura et al. 2008), usually traces of drill holes are infrequent, often in barely $1 \%$ of specimens (Taddei Ruggiero \& Bitner 2008, Bitner et al. 2013a, Bitner \& Müller 2015, Bitner \& Motchurova-Dekova 2016). At Dnipropetrovsk the frequency of drill holes in brachiopods is relatively high; 130 drilled specimens $(9.6 \%)$ were found among 1356 specimens examined (Fig. 11, Table 1). Drillings were observed on Terebratulina tenuistriata, Megathiris detruncata, Argyrotheca lunula, A. megapora, Bronnothyris danaperensis, Joania ukrainica, Megerlia sp., and Lacazella mediterranea. No drill holes were observed on Discradisca sp., Novocrania cf. anomala, and Platidia sp. The much higher drilling frequencies among the representatives of Megathyrididae may suggest taxonomic selectivity. We also observe valve selectivity; the dorsal valve was drilled at a higher frequency. Drill holes occur on 40 ventral and 91 dorsal valves, in one case on both valves (Table 1). Contrary to thecideides whose ventral valve is cemented to the substrate, the dorsal valve preference is difficult to explain in the megathyridids as their shell is oriented in a vertical position with both valves equally exposed. However, such preference for the dorsal valve was also recognized in other Cenozoic populations (e.g. Bitner et al. 2013a, Bitner \& Müller 2015). Additionally, in the ribbed brachiopods, such as $M$. detruncata and $A$. lunula, preferential drill hole siting is observed. Drill holes are very often situated between ribs (Fig. 11 E-G, L-N) where the shell can be up to half as thick as on ribs.

On some specimens failed drill holes are visible (Fig. 11K-M). According to Robinson (2014b) some abandoned drill holes can be unrecognized, repaired drill holes. Predatory drilling by gastropods is usually fatal, but brachiopods that survive attacks are capable of repairing their shells (Alexander et al. 1992, Hiller 2014, Robinson 


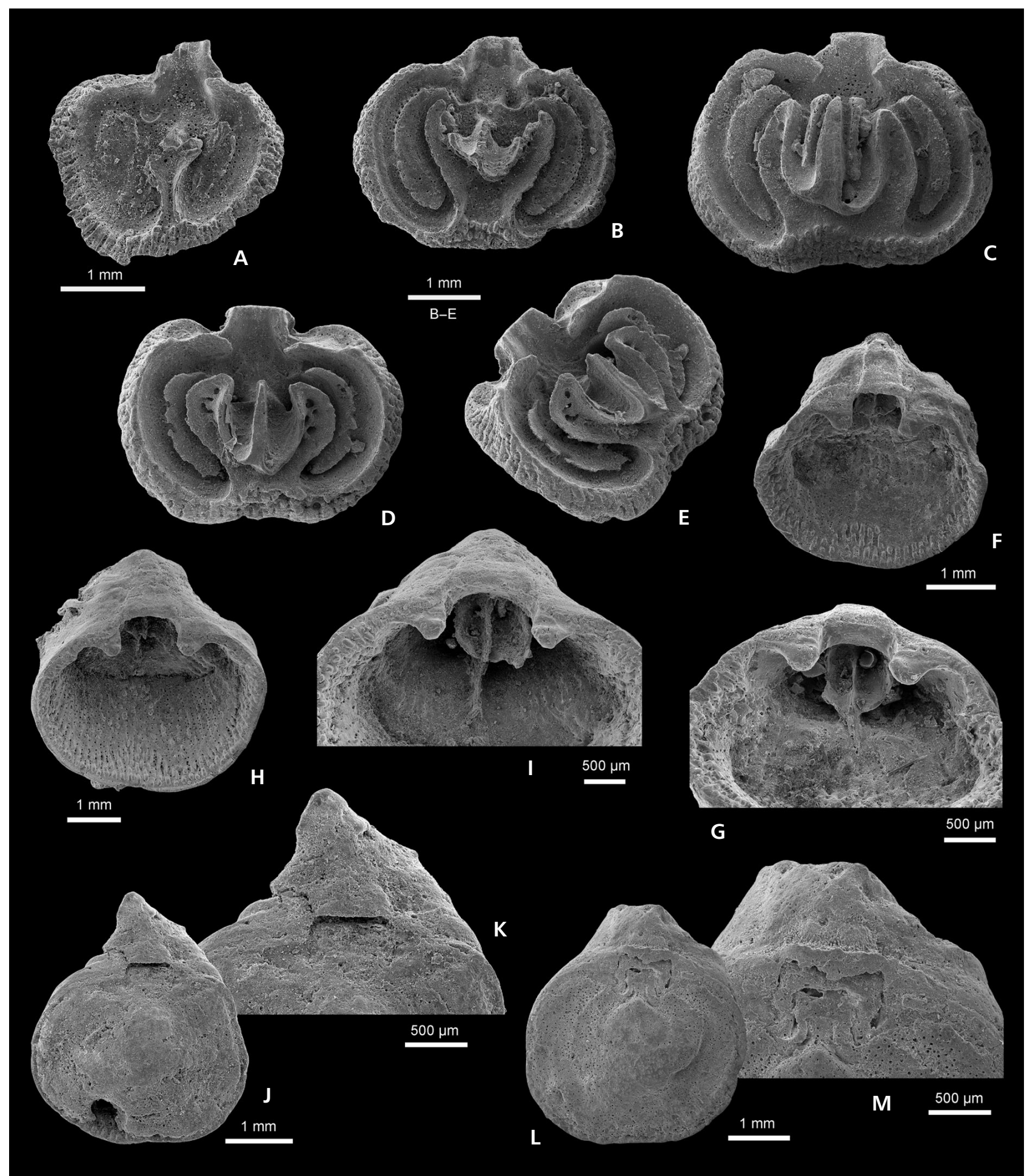

Figure 10. Lacazella mediterranea (Risso, 1826), Upper Eocene, Dnipropetrovsk, Ukraine. • A-E - dorsal valves; A - interior view of juvenile specimen, no. UDB 147; B - interior view, no. UDB 148; C - interior view, no. UDB 149; D, E - interior and oblique views, no. UDB 150 . $\bullet$ F-H - ventral valves; F, G - interior view and enlargement tilted view of posterior part to show hemispondylium, no. UDB 151; H, I-interior and tilted views, no. UDB 152. • J-M - dorsal views of complete specimens, and enlargement of umbonal part to show pseudodeltidium; J, K - no. UDB 153; L, M - no. UDB 154. All SEM. 
Table 1. Drill hole data for the Late Eocene brachiopods from Dnipropetrovsk.

\begin{tabular}{|c|c|c|c|c|c|}
\hline Species & Number undrilled & Number drilled (\% drilled) & Drilled on ventral & Drilled on dorsal & Drilled on both valves \\
\hline Discradisca sp. & 4 & $0(0.0 \%)$ & 0 & 0 & 0 \\
\hline Novocrania cf. anomala & 6 & $0(0.0 \%)$ & 0 & 0 & 0 \\
\hline Terebratulina tenuistriata & 92 & $5(5.2 \%)$ & 5 & 0 & 0 \\
\hline Megathiris detruncata & 238 & $32(11.8 \%)$ & 14 & 18 & 0 \\
\hline Argyrotheca lunula & 192 & $27(12.3 \%)$ & 11 & 16 & 0 \\
\hline Argyrotheca megapora & 75 & $3(3.8 \%)$ & 1 & 2 & 0 \\
\hline Bronnothyris danaperensis & 167 & $43(20.5 \%)$ & 5 & 37 & 1 \\
\hline Joania ukrainica & 5 & $1(16.7 \%)$ & 1 & 0 & 0 \\
\hline Platidia sp. & 3 & $0(0.0 \%)$ & 0 & 0 & 0 \\
\hline Megerlia sp. & 8 & $1(11.1 \%)$ & 1 & 0 & 0 \\
\hline Lacazella mediterranea & 436 & $18(4.0 \%)$ & 1 & 17 & 0 \\
\hline Totals & 1226 & $130(9.6 \%)$ & 39 & 90 & 1 \\
\hline
\end{tabular}

2014b) and in the investigated assemblage some evidence of drill hole repair was seen. In two cases two repairs on one valve were observed (Fig. $11 \mathrm{H}-\mathrm{J}, \mathrm{N}-\mathrm{P}$ ). The missing part of a shell is repaired in two ways: by a thin flat sheet growing across the inner edge of the drill hole (Fig. 11H, I) or by an inwardly directed, low to inflated blister (Fig. 11J, $\mathrm{O}, \mathrm{P})$. The drill hole diameters range from 0.3 to $0.7 \mathrm{~mm}$ and the holes are cylindrical in shape, corresponding to muricid attacks.

\section{Conclusions}

The brachiopod fauna collected from the Priabonian sands in the Rybalsky Quarry at Dnipropetrovsk, eastern Ukraine (Fig. 1) comprises eleven species belonging to ten genera, eight articulate and two inarticulate brachiopods. The latter are represented by the discinid Discradisca sp. and the craniid Novocrania cf. anomala. Although thecideides have only one representative, Lacazella mediterranea, this species is the most common in the studied assemblage. Among terebratulides there are representatives of four families, however, the families Cancellothyrididae, Platidiidae and Kraussinidae have one representative each, Terebratulina tenuistriata, Platidia sp. and Megerlia sp., respectively. The family Megathyrididae is the most common and diverse group in the assemblage with five species have been recognized: Megathiris detruncata, two species of Argyrotheca, A. lunula and A. megapora, Bronnothyris danaparensis, and Joania ukrainica. The two latter species are described as new and together with $A$. megapora can be considered as potentially endemic to Ukraine. The megathyridids and Lacazella mediterranea dominate, constituting more than $90 \%$ of the material. The rhynchonellides and large, short-looped smooth terebratulides are missing in the Dnipropetrovsk assemblage. Brachiopod communities containing only such micromorphic forms are characteristic for the Paleogene and Neogene of Europe (e.g. Popiel-Barczyk \& Barczyk 1987; Bitner 1990, 1993, 2000; Bitner \& Kaim 2004; Dulai 2007, 2010, 2011; Bitner \& Dulai 2008; Bitner et al. 2013a, 2016; Bitner \& Motchurova-Dekova 2016).

The species composition differs slightly along the section. All eleven species occur only in the upper part of the section (UDR 1, see fig. 3 in Müller \& Rozenberg 2003). In that part brachiopods are also most abundant; about 800 specimens were collected from the UDR 1 . In other parts of the section brachiopods are less numerous, represented by 7-8 species. Four species, Megathiris detruncata, Argyrotheca lunula, Bronnothyris danaparensis, and Lacazella mediterranea, were found in all samples.

The genera Discradisca, Novocrania Megathiris, Joania, Megerlia and Platidia are reported for the first time from the Eocene of Ukraine. Additionally, there are the

Figure 11. Drilled brachiopods, Upper Eocene, Dnipropetrovsk, Ukraine. • A-D - Lacazella mediterranea (Risso, 1826); A, B - ventral valve and a close-up image of drill hole (B), no. UDB 207; C - exterior of dorsal valve, no. UDB 208; D - exterior of dorsal valve, no. UDB 209. $\bullet$ E-G - Megathiris detruncata (Gmelin, 1791); E - exterior of dorsal valve, no. UDB 210; F - exterior of ventral valve, no. UDB 211; G - dorsal view of complete specimen, no. UDB 212. • H-K - Bronnothyris danaperensis sp. nov.; H-J - exterior and interior views of ventral valve, and a close-up image (I) of partially repaired drill hole, no. UDB 213; K - exterior of dorsal valve, no. UDB 214. • L-P - Argyrotheca lunula (von Koenen, 1894); L, M - ventral valve exterior and close-up of failed drill hole, no. UDB 215; N-P - exterior and interior views of ventral valve, inflated blister repair of drill holes arrowed, and close-up (P) of blister surface, no. UDB 216. All SEM. 


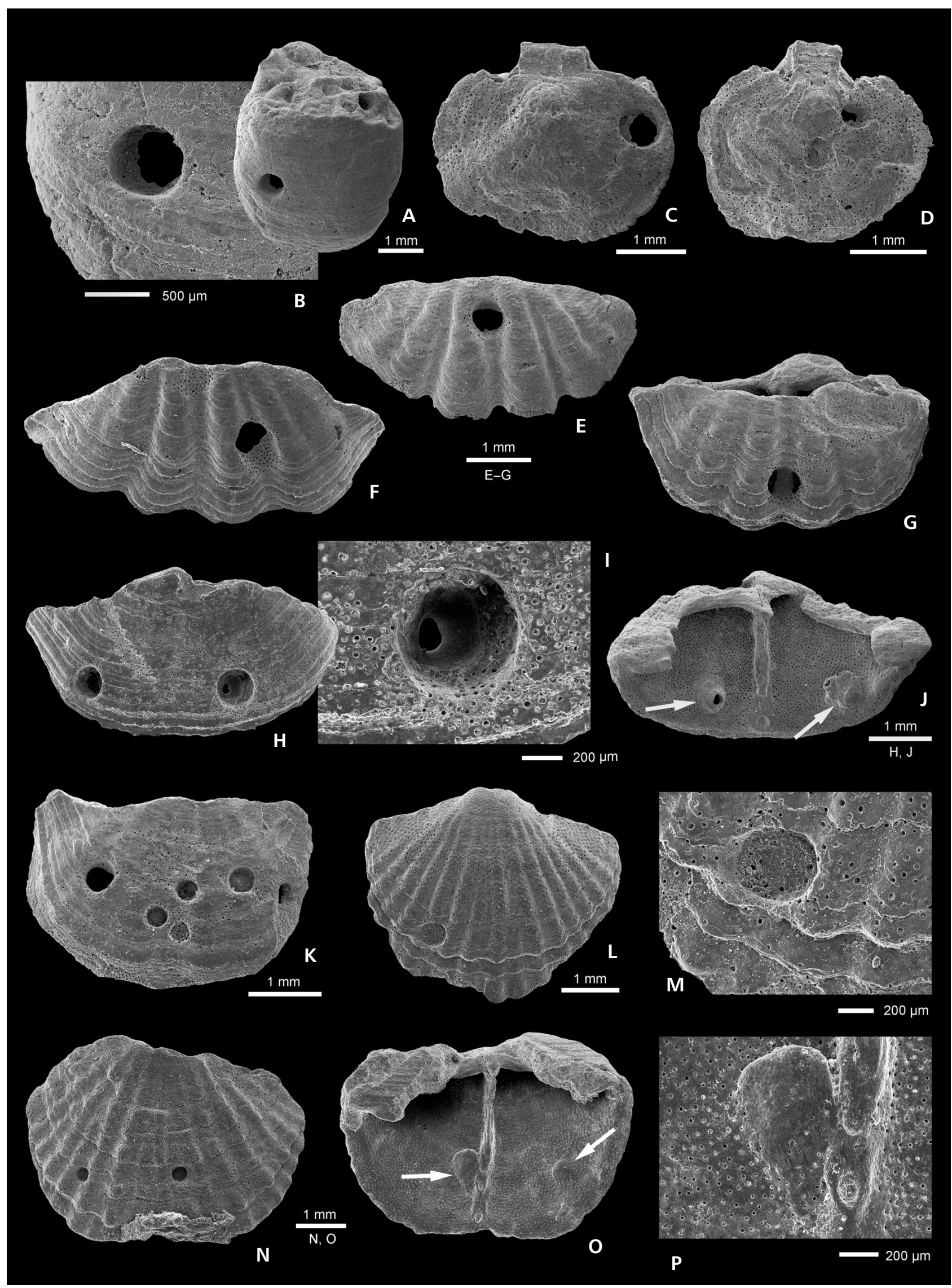


oldest occurrences of Joania and Megerlia, extending their stratigraphical range from the Oligocene to the Eocene.

Although many Eocene species have a very wide geographical distribution throughout the whole of Europe, such as T. tenuistriata, $M$. detruncata, and L. mediterranea described here, the Dnipropetrovsk fauna displays greater similarity (having five species in common) to that of the Latdorf basin of northern Germany (von Koenen 1894) than to any sample from southern Europe (Bitner 2000, Bitner \& Dieni 2005, Bitner \& Dulai 2008, Dulai et al. 2010, Bitner et al. 2011, Dulai 2011). The molluscan fauna from the Rybalsky Quarry is also most similar to the fauna from Latdorf (Amitrov 2008).

\section{Acknowledgements}

Dr. B.L. Cohen (University of Glasgow, Glasgow) is thanked for reading an earlier version of the manuscript, making useful comments and improving the English. Dr T.A. Stefanska (Oles Honchar Dnipropetrovsk National University, Dnipropetrovsk) is thanked for help with papers not available to us and for donating several studied brachiopods. A. Hołda-Michalska (Institute of Paleobiology, Warszawa) is thanked for help in the preparation of Fig. 1. We would like to thank D.E. Lee (University of Otago, Dunedin) and E. Simon (Royal Belgian Institute of Natural Sciences, Brussels) for their comments.

\section{References}

Alexander, R.R., James, M.A. \& Ansell, A.D. 1992. Survival and repair of surgical and natural shell damage in the articulate brachiopod Terebratulina retusa (Linnaeus). Historical Biology 6, 221-231. DOI 10.1080/10292389209380430

Álvarez, F., Brunton, C.H.C. \& Long, S.L. 2008. Loop ultrastructure and development in recent Megathiridoidea, with description of a new genus, Joania (type species Terebratula cordata Risso, 1826), 391-403. In CUSACK, M. \& HARPER, D.A.T. (eds) Brachiopod Research into the Third Millennium. Transactions of the Royal Society of Edinburgh, Earth Environmental Science 98.

Álvarez, F., MartíneZ, A., NúÑEZ, L. \& NúÑEZ, J. 2005. Sobre la presencia en Canarias de varias especies de braquiópodos (Brachiopoda: Rhynchonellata) en cuevas y cornisas submarinas. Vieraea 33, 261-279.

Amitrov, O.V. 2008. The current state of study of the gastropods of the Mandrikovka Beds (Upper Eocene of Ukraine), with the description of a new species of Conorbis. Paleontological Journal 42, 581-584. DOI 10.1134/S0031030108060026

Amitrov, O.V. \& Zhegallo, E.A. 2007. Triphorids (Gastropoda: Triphoridae) from the Upper Eocene of Ukraine. Paleontological Journal 41, 370-381. DOI 10.1134/S003103010704003X

Backhaus, E. 1959. Monographie der cretacischen Thecideidae (Brach.). Mitteilungen aus dem Gelogischen Staatsinstitut in Hamburg 28, 5-90.
BAumiller, T.K. \& Bitner, M.A. 2004. A case of intense predatory drilling of brachiopods from the Middle Miocene of southeastern Poland. Palaeogeography, Palaeoclimatology, Palaeoecology 214, 85-95. DOI 10.1016/S0031-0182(04)00393-1

Baumiller, T.K., Bitner, M.A. \& Emig, C.C. 2006. High frequency of drill holes in brachiopods from the Pliocene of Algeria and its ecological implications. Lethaia 39, 313-320. DOI 10.1080/00241160600847546

Berezovsky, A.A. 2014. New species of Asperarca (Bivalvia, Arcidae) from the Upper Eocene of Ukraine. Paleontological Journal 49, 575-579. DOI 10.1134/S0031030114060033

Berezovsky, A.A. 2015. New species of Limopsis (Bivalvia) from the Upper Eocene of Ukraine. Paleontological Journal 49, 230-237. DOI 10.1134/S0031030115030028

Bitner, M.A. 1990. Middle Miocene (Badenian) brachiopods from the Roztocze Hills, south-eastern Poland. Acta Geologica Polonica 40, 129-157.

Bitner, M.A. 1993. Middle Miocene (Badenian) brachiopods from coral reefs of north-western Bulgaria. Acta Geologica Polonica 43, 147-155.

BitNER, M.A. 2000. Lower Eocene (Middle Ilerdian) brachiopods from the Campo region, Central Pyrenees, north-eastern Spain. Revista Española de Paleontología 15, 117-128.

Bitner, M.A. \& BoukHARY, M. 2009. First record of brachiopods from the Eocene of Egypt. Natura Croatica 18, 393-400.

Bitner, M.A. \& Boukhary, M. 2012. First record of Eocene brachiopods from the United Arab Emirates, Arabian Gulf and their paleogeographical significance. Neues Jahrbuch für Geologie und Paläontologie Abhandlungen 265, 275-279. DOI 10.1127/0077-7749/2012/0263

Bitner, M.A. \& CAHUZAC, B. 2013. New record of Discradisca (Brachiopoda: Discinidae) from the Early Miocene of the Aquitaine Basin, south-western France. Comptes Rendus Palevol 12, 23-29. DOI 10.1016/j.crpv.2012.10.001

Bitner, M.A. \& DienI, I. 2005. Late Eocene brachiopods from the Euganean Hills (NE Italy). Eclogae Geologicae Helvetiae 98, 103-111. DOI 10.1007/s00015-005-1145-x

Bitner, M.A. \& Dulai, A. 2004. Revision of Miocene brachiopods of the Hungarian Natural History Museum, with special regard to the Meznerics collection. Fragmenta Palaeontologica Hungarica 22, 69-82.

Bitner, M.A. \& DUlaI, A. 2008. Eocene micromorphic brachiopods from the north-western Hungary. Geologica Carpathica $59,31-43$.

Bitner, M.A. \& KaIM, A. 2004. The Miocene brachiopods from the silty facies of the intra-Carpathian Nowy Sacz Basin (Poland). Geological Quarterly 48, 193-198.

Bitner, M.A. \& KROH, A. 2011. First record of the genus Bronnothyris (Brachiopoda: Megathyrididae) from the Oligocene of the Mainz Basin, Germany. Geologica Carpathica 62, 203-209. DOI 10.2478/v10096-011-0017-8

Bitner, M.A. \& Moissette, P. 2003. Pliocene brachiopods from north-western Africa. Geodiversitas 25, 463-479.

Bitner, M.A. \& Motchurova-Dekova, N. 2016. Middle Miocene (Badenian) brachiopods from Yasen, northwestern Bulgaria: taxonomic composition and biogeographical significance. Neues Jahrbuch für Geologie und Paläontologie, Abhandlungen 279, 7-22. DOI 10.1127/njgpa/2016/0536 
Bitner, M.A. \& Müller, A. 2015. Brachiopods from the Silberberg Formation (Late Eocene to Early Oligocene) of Atzendorf, Central Germany. Paläontologische Zeitschrift 89, 673-688. DOI 10.1007/s12542-015-0262-8

Bitner, M.A. \& Schneider, S. 2009. The Late Burdigalian (Ottnangian) brachiopod fauna from the northern coast of the Upper Marine Molasse Sea in Bavaria, Southern Germany. Neues Jahrbuch für Geologie und Paläontologie, Abhandlungen 254, 117-133. DOI 10.1127/0077-7749/2009/0006

Bitner, M.A., Astibia, H. \& Payros, A. 2016. Middle Eocene (Bartonian) brachiopods from the Pamplona Basin, Navarre, South-Western Pyrenees. Batalleria 23, 1-7.

Bitner, M.A., Dulai, A. \& Galácz, A. 2011. Middle Eocene brachiopods from the Szốc Limestone Formation (Bakony Mountains, Hungary), with description of a new genus. Neues Jahrbuch für Geologie und Paläontologie, Abhandlungen 259, 113-128. DOI 10.1127/0077-7749/2010/0113

Bitner, M.A., Lozouet, P. \& Cahuzac, B. 2013a. Upper Oligocene (Chattian) brachiopod fauna from the Aquitaine Basin, southwestern France and its paleoenvironmental implications. Geodiversitas 35, 579-606. DOI 10.5252/g2013n3a4

BitNer, M.A., ZÁGORŠEK, K. \& HLADILOVÁ, Š. 2013b. Deep-water brachiopod assemblage from the Middle Miocene of Kralice nad Oslavou, Moravia, southeastern Czech Republic. Comptes Rendus Palevol 12, 81-89.

DOI 10.1016/j.crpv.2013.01.004

Blochmann, F. 1892. Untersuchungen über den Bau der Brachiopoden. 1. Die Anatomie von Crania anomala, O.F. Müller. 4 Vols. 68 pp. Verlag Von Gustav Fischer, Jena.

Bosquet, J. 1864. Description d'une espèce nouvelle du genre Argiope de terrain oligocène inférieur du nord de l'Allemange. 6 pp. Leiter-Nypels, Maestricht.

Brunton, C.H.C., Cocks, L.R.M. \& Dance, S.P. 1967. Brachiopods in the Linnaean Collection. Proceedings of the Linnean Society of London 178, 161-183.

DOI 10.1111/j.1095-8312.1967.tb00972.x

Cohen, B.L., Kaulfuss, A. \& LÜter, C. 2014. Craniid brachiopods: aspects of clade structure and distribution reflect continental drift (Brachiopoda: Craniiformea). Zoological Journal of the Linnean Society 171, 133-150. DOI 10.1111/zoj.12121

Costa, O.G. 1852. Class V, Brachiopodi. Fauna del Regno di Napoli 10, 1-60.

DALL, W.H. 1870. A revision of the Terebratulidae and Lingulidae. American Journal of Conchology 50, 1-445.

DALL, W.H. 1900. Some names which must be discarded. Nautilus 14(4), 44-45.

DALL, W.H. 1920. Annotated list of the Recent Brachiopoda in the collection of the United States National Museum, with description of thirty-three new forms. Proceedings of the United States National Museum 57, 261-377. DOI 10.5479/si.00963801.57-2314.261

DulAI, A. 2007. Badenian (Middle Miocene) micromorphic brachiopods from Bánd and Devecser (Bakony Mountains, Hungary). Fragmenta Palaeontologica Hungarica 24-25, 1-13.

DulaI, A. 2010. Early Messinian (Late Miocene) micromorphic brachiopods from Borelli (Italy, Piemonte). Fragmenta Palaeontologica Hungarica 28, 21-31.

DulaI, A. 2011. Late Eocene (Priabonian) micromorphic brachio- pods from the Upper Austrian Molasse Zone. Memoirs of the Association of Australasian Palaeontologists 41, 295-313.

DulaI, A. 2013. Sporadic Miocene brachiopods in the Naturalis Biodiversity Center (Leiden, the Netherlands): Records from the Mediterranean, the North Sea and the Atlantic Ocean. Fragmenta Palaeontologica Hungarica 30, 15-51.

Dulai, A. 2015. Central Paratethyan Middle Miocene brachiopods from Poland, Hungary and Romania in the Naturalis Biodiversity Center (Leiden, the Netherlands). Scripta Geologica 149, 185-211.

Dulai, A., HradeckÁ, L., KonZalová, M., Less, G., Švábenická, L. \& LobitZER, H. 2010. An Early Eocene fauna and flora from "Rote Kirche" in Gschliefgraben near Gmunden, Upper Austria. Abhandlungen der Geologischen Bundesanstalt 65, 181-201.

Elliott, G.F. 1958. Classification of thecidean brachiopods. Journal of Paleontology 32, 373.

EMIG, C.C. 2014. Novocrania turbinata synonyme de N. anomala. Carnets de Géologie [Notebooks on Geology], Brest 14, 159-170.

EmIG, C.C. 2016. Les brachiopodes des côtes françaises métropolitaines, 129-141. In Álvarez, F., Emig, C.C. \& TRÉGUIER, J. (eds) Brachiopodes actuels: historique et révision de la collection D.-P. Ehlert (Laval); brachiopodes des côtes françaises métropolitaines. Bulletin de la Société des Sciences naturelles de l'Ouest de la France hors-série 2016-1.

GmeLIN, J.F. 1791. Systema Naturae. 13 ed., 3021-4120. Beer, Lipsiae.

GRAY, J.E. 1840. Synopsis of the contents of the British Museum, $42^{\text {nd }}$ edition. 370 pp. G. Woodfall, London.

HARPER, E.M. 2005. Evidence of predation damage in Pliocene Apletosia maxima (Brachiopoda). Palaeontology 48, 197-208. DOI 10.1111/j.1475-4983.2004.00433.x

HARPER, E.M. 2011. What do we really know about predation on modern rhynchonelliforms? Memoirs of the Association of Australian Paleontologists 41, 45-57.

HiLLER, N. 2011. Micromorphic brachiopods from the Early Miocene (Otaian) of Northland, New Zealand. New Zealand Journal of Geology and Geophysics 54, 75-87. DOI 10.1080/00288306.2011.537608

HiLLER, N. 2014. Drill holes and shell repair in brachiopods from a Late Cretaceous (Maastrichtian) oyster reef, North Canterbury, New Zealand. Lethaia 49, 83-90. DOI 10.1016/j.cretres.2014.01.001

Hiller, N., MacKinnon, D.I. \& Nielsen, S.N. 2008. A review of the systematics, biogeography, and evolutionary relationships of Recent and fossil brachiopods of the Superfamily Kraussinoidea Dall, with descriptions of two new fossil species from New Zealand and Chile, 379-390. In CusACK, M. \& HARPER, D.A.T. (eds) Brachiopod Research into the Third Millenium. Earth and Environmental Science Transactions of the Royal Society of Edinburgh 98. DOI 1017/S1755691007078474

ICZN 1999. International Code of Zoological Nomenclature. International Commission on Zoological Nomenclature. Fourth edition. xxix +306 pp. International Trust for Zoological Nomenclature, London.

KING, W. 1850. A monograph of the Permian Fossils of England. 
Palaeontographical Society Monograph 3, 1-258. DOI 10.5962/bhl.title.114608

Koenen, A. von 1894. Das Norddeutsche Unter-Oligocän und seine Mollusken-Fauna. Abhandlungen zur geologischen Specialkarte von Preussen und den Thüringischen Staaten 10, 1250-1392.

Kroh, A., Bitner, M.A. \& Ávila, S.P. 2008. Novocrania turbinata (Brachiopoda) from the Early Pliocene of the Azores (Portugal). Acta Geologica Polonica 58, 473-478.

LeE, D.E. \& Brunton, C.H.C. 1986. Neocrania n. gen., and a revision of Cretaceous-Recent brachiopod genera in the family Craniidae. Bulletin of the British Museum (Natural History), Geology 40, 141-160.

LeE, D.E. \& BRUnTon, C.H.C. 2001. Novocrania, a new name for the genus Neocrania Lee \& Brunton, 1986 (Brachiopoda, Craniida), preoccupied by Neocrania Davis, 1978 (Insecta, Lepidoptera). Bulletin of the Natural History Museum, Geology Series 57, 5.

Leymerie, M.A. 1846. Mémoire sur le terrain à Nummulites (Epicrétacé) des Corbières et de la Montagne Noire. Mémoires de la Société Géologique de France, deuxième série 8, 337-373.

LinNaeus, C. 1758. Systema Naturae per Regna tria Naturae, secudum classes, ordines, genera, species. 10th edition. 823 pp. Holmiae, Stockholm.

LinNAEus, C. 1767. Systema Naturae, sive Regna tria Naturae systematicae proposita per Classes, Ordines, Genera et Species. 12th edition. 533-1327 pp. Holmiae, Stockholm.

LogAN, A. 1977. Reef-dwelling articulate brachiopods from Grand Cayman, B.W.I. Proceedings of the Third International Coral Reef Symposium, Miami 1, 87-93.

LogAN, A. 1979. The Recent Brachiopoda of the Mediterranean Sea. Bulletin de l'Institut Océanographique, Monaco 72, $1-112$.

LogAn, A. 2007. Geographic distribution of extant articulated brachiopods, 3082-3115. In SELDEN, P.A. (ed.) Treatise on Invertebrate Paleontology. Part H. Brachiopoda Revised. Volume 6. Geological Society of America and University of Kansas, Boulder, Colorado \& Lawrence.

Logan, A. \& BAKer, P. 2013. The development and shell microstructure of the pseudodeltidium and interarea in thecideide brachiopods. Palaeontology 56, 433-455. DOI 10.1111/pala.12001

LogAn, A. \& Long, S.L. 2001. Shell morphology and geographical distribution of Neocrania (Brachiopoda, Recent) in the eastern North Atlantic and Mediterranean Sea, 71-79. In Brunton, C.H.C., Cocks, L.R.M. \& Long, S.L. (eds) Brachiopods Past and Present. Systematics Association, Special Volume Series 63.

Logan, A., Bianchi, C.N., Morri, C. \& Zibrowius, H. 2004. The present-day Mediterranean brachiopod fauna: diversity, life habits, biogeography and paleobiogeography, 163-170. In Ros, J.D., Packard, T.T., Gili, J.M., Pretus, J.L. \& Blasco, D. (eds) Biological oceanography at the turn of the Millenium. Scientia Marina 68 (Suppl. 1).

Makarenko, D.E. 1974. A new species of Crania from the Upper Eocene of the Ukraine. Paleontologicheskij Sbornik 11, 46-49. [in Russian]

Menke, C.T. 1828. Synopsis methodical molluscorum generum omnium et specierum earum, quae in Museo Menkeano adservantur. 91 pp. G. Uslar, Pyrmonti.

Muir-Wood, H.M. 1955. A history of the classification of the phylum Brachiopoda. Bulletin of the British Museum (Natural History) 78, 1-124.

Müller, O.F. 1776. Zoologice Danicae Prodromus, seu Animalium Danice et Norvegice indigenarum characteres, nomina, et synonyma imprimis popularium. $282 \mathrm{pp}$. Typis Hallageriis, Havniæ. DOI 10.5962/bhl.title.13268

MüLler, A. 2011. Der Steinbruch Mammendorf NW Magdeburg - ein Felslitoral der unteroligozänen Nordsee. Geologica Saxonica 57, 3-120.

Müller, A. \& Rozenberg, A. 2003. Teleostei-Otolithen aus den Mandrikovka-Schichten (Priabonium) von Dnepropetrovsk (Ukraine). Paläontologische Zeitschrift 77(2), 361-387. DOI 10.1007/BF03006948

Munier-Chalmas, E.P. 1880. Note sommaire sur les genres de la famille des Thecideidae. Bulletin de la Société géologique de France (séries 3) 8, 279-280.

OrbignY, A. D' 1845. Mollusques. In Historique physique, politique et naturelle de l'île de Cuba, vol. 2. ed. M. Ramon de la Sarga, 1-376. A. Bertrand, Paris.

OrbignY, A. D’ 1847. Considérations zoologiques et géologiques sur les brachiopodes ou palliobranches. Comptes Rendus hebdomadaires des Séances de l'Académie des Sciences 25, 266-269.

Pajaud, D. 1970. Monographie des Thécidées (Brachiopodes). Mémoires de la Société géologique de France (Nouvelle Série) $112,1-349$.

Pajaud, D. \& Plaziat, J.C. 1972. Brachiopodes thanétiens du synclinal sud-cantabrique au S-E de Vitoria (Pays basque espagnol). Étude systématique et interprétation paléoécologique. Bulletin de la Société d'Histoire naturelle de Toulouse 108, 446-473.

Poli, J.X. 1795. Testacea Utriusque Siciliae. Vol. 2. 189 pp. Regio Typographeio, Parma.

Popiel-BARCZYK, E. \& BARCZYK, W. 1987. Eocene brachiopods from Wola Łużańska and Skalnik in the Central Carpathians. Acta Geologica Polonica 37, 93-104.

Popiel-Barczyk, E. \& BARCZyK, W. 1990. Middle Miocene (Badenian) brachiopods from the southern slopes of the Holy Cross Mountains, Central Poland. Acta Geologica Polonica 40, 159-181.

Popiel-Barczyk, E. \& Smirnova, T.N. 1978. New genus megathyrid (Brachiopoda) from the Middle Vistula Gorge. Prace Muzeum Ziemi 12, 3-86.

Risso, A. 1826. Histoire naturelle des principales productions de l'Europe méridionale, et particulièrement de celles des environs de Nice et des Alpes-Maritimes, 4.439 pp. F.G. Levrault, Paris.

Robinson, J. 2014a. The muscles, body wall and valve-opening mechanism of extant craniid (inarticulated) brachiopods. Journal of Natural History 48, 1231-1252.

DOI 10.1080/00222933.2013.840941

RoBInson, J.H. 2014b. Repair of gastropod drillholes in a platidiid brachiopod from Fiordland, New Zealand. Lethaia 47, 31-37. DOI 10.1111/let.12035

Robinson, J. 2015. A review of extant species in the craniid brachiopod genus Novocrania, p. 73. In HuANG, B. \& SHEN, S. 
(eds) The Brachiopod World, Abstracts for $7^{\text {th }}$ International Brachiopod Congress, Nanjing, China, 2015.

SANDBERger, C.L.F. 1862. Die Conchylien des Mainzer Tertiärbeckens. 233-270 pp. C.W. Kreidel's Verlag, Wiesbaden.

SCACChI, A. \& PhiLIPPI, R.A. 1844. Enumeratio Molluscorum Siciliae. 303 pp. E. Anton, Halle.

Sirenko, B.I. \& Dell'Angelo, B. 2015. Makarenplax gen. nov. and Makarenkoplacidae fam. nov. (Mollusca: Polyplacophora): Chitonida) from the Palaeogene of the Ukraine. Proceedings of the Zoological Institute RAS 319, 528-535.

Steinich, G. 1965. Die articulaten Brachiopoden der Rügener Schreibkreide (Unter-Maastricht). Paläontologische Abhandlungen, Paläozoologie 2, 1-220.

StenZEL, H.B. 1964. Stratigraphic and paleoecologic significance of a new Danian brachiopod species from Texas. Geologische Rundschau 54, 619-631. DOI 10.1007/BF01820747

SysterovA, D.E. 2012. State of knowledge of Paleogene brachiopods and approaches to their futher researches. Geologo-Mineralogichnij Visnik 28, 74-77. [in Russian]

Systerova, D.E. 2014. Genus Bronnothyris (Brachiopoda) from the Upper Eocene deposits of Dnepropetrovsk. Mizhnarodna Naukovo-Tekhnichna Konferentsya, Stalij rozbitok promislovosti ta sysshlstva, Kryvyi Rih, 22-25 October 2014, 19-21. [in Russian]

TAdDei RugGiero, E. 1993. Argyrotheca ageriana sp. nov. (Brachiopoda): paleoecology and shell ultrastructure. Palaeogeography, Palaeoclimatology, Palaeoecology 100, 217-227. DOI 10.1016/0031-0182(93)90044-J

TAdDei Ruggiero, E. \& Bitner, M.A. 2008. Bioerosion on the brachiopod shell - a Cenozoic perspective, 369-378. In Cusack, M. \& Harper, D.A.T. (eds) Brachiopod Research into the Third Millenium. Earth and Environmental Science Transactions of the Royal Society of Edinburgh 98.

Thomson, J.A. 1926. A revision of the subfamilies of the
Terebratulidae (Brachiopoda). The Annals and Magazine of Natural History (9)18, 523-530.

DOI 10.1080/00222932608633548

Thomson, J.A. 1927. Brachiopod morphology and genera (Recent and Tertiary). New Zealand Board of Science and Art 7, $1-338$.

Tuura, M.E., Baumiller, T.K. \& McNamara, K.J. 2008. Drill holes in Australian Cainozoic brachiopods. Historical Biology 20, 203-212. DOI 10.1080/08912960802580154

Vincent, E. 1923. Quelques remarques sur des Brachiopodes tertiairies de Belgique et description d'une espèce nouvelle d'Argyrotheca. Annales de la Société Royale Zoologique de Belgique 53, 49-53.

WaAgen, W.H. 1883. Salt Range fossils, vol. I, part 4. Productus Limestone fossils, Brachiopoda. Memoirs of Geological Survey of India, Palaeontologia Indica (series 13) 2, 391-546.

WAAGEN, W.H. 1885. Salt Range fossils, vol. I, part 4. Productus Limestone fossils, Brachiopoda. Memoirs of Geological Survey of India, Palaeontologia Indica (series 13) 5, 729-770.

Zágoršek, K., Nehyba, S., Tomanová Petrová, P., Hladilová, Š., Bitner, M.A., Doláková, N., Hrabovský, J. \& JašKová, V. 2012. Local catastrophe caused by tephra input near Přemyslovice (Moravia, Czech Republic) during the Middle Miocene. Geological Quarterly 56, 269-284.

DOI 10.7306/gq.1021

ZeLINSKAYA, V.A. 1962. Brachiopods from the Upper Eocene of the Ukraine. Paleontologicheskij Zhurnal 2, 106-111. [in Russian]

Zelinskaya, V.A. 1970. The new terebratulids of the Eocene of Ukraine. Paleontologicheskij Sbornik 7, 55-61. [in Russian]

Zelinskaya, V.A. 1975. Brachiopods from the Paleogene of the Ukraine. 148 pp. Naukova Dumka, Kiev. [in Russian]

ZelinskAyA, V.A. 1977. First Lacazella (Brachiopoda) in Paleogene of the Ukraine. Dopovidi Akademii Nauk Ukrainskoj RSR 8, 687-690. [in Ukrainian] 